\title{
Synthesis, Relaxometric and Photophysical Properties of a New pH-Responsive MRI Contrast Agent: The Effect of Other Ligating Groups on Dissociation of a p-Nitrophenolic Pendant Arm
}

\author{
Mark Woods ${ }^{\dagger}, \ddagger$, Garry E. Kiefer ${ }^{\star}, \S$, Simon Bott ${ }^{\|}$, Aminta Castillo-Muzquiz ${ }^{\ddagger}$, Carrie \\ Eshelbrenner $\ddagger$, Lydie Michaudet ${ }^{\ddagger}$, Kenneth McMillan $\S$, Siva D. K. Mudigunda ${ }^{\dagger}$, Doug \\ Ogrin $^{\perp}$, Gyula Tircsó $\ddagger$, Shanrong Zhang $\#$, Piyu Zhao ${ }^{\ddagger}$, and A. Dean Sherry ${ }^{\star}, \ddagger, \#$ \\ tContribution from the Macrocyclics, 2110 Research Row, Suite 425, Dallas, Texas 75235 \\ ¥Department of Chemistry, University of Texas at Dallas, P.O. Box 803066, Richardson, Texas \\ 75083 \\ §Dow Chemical Company, 2301 North Brazosport BouleVard, Freeport, Texas 77541 \\ "Department of Chemistry, University of Houston, 136 Fleming Building, Houston, Texas \\ 77204-5003 \\ ${ }^{\perp}$ Department of Chemistry, Rice University, P.O. Box 1892, Houston, 77251-1892, and Rogers \\ Magnetic Resonance Center \\ \#Department of Radiology, University of Texas Southwestern Medical Center, 5323 Harry Hines \\ BIVd., Dallas, Texas 75390-9085
}

\section{Abstract}

Two gadolinium(III) chelates, GdNP-DO3A (1-methlyene-( $p$-NitroPhenol)-1,4,7,10tetraazacycloDOdecane-4,7,10-triAcetate) and GdNP-DO3AM (1-methlyene( $p$ -

NitroPhenol)-1,4,7,10-tetraazacycloDOdecane-4,7,10-triacetAMide), containing a single nitrophenolic pendant arm plus either three acetate or three amide pendant arms were synthesized and characterized. The properties of the gadolinium, terbium, and dysprosium complexes of these ligands were examined as a function of $\mathrm{pH}$. The extent and mechanism of the changes in water relaxivity with $\mathrm{pH}$ of each gadolinium complex was found to differ substantially for the two complexes. The water relaxivity of Gd(NP-DO3A) increases from $4.1 \mathrm{mM}^{-1} \mathrm{~s}^{-1}$ at $\mathrm{pH} 9$ to 7.0 $\mathrm{mM}^{-1} \mathrm{~s}^{-1}$ at $\mathrm{pH} 5$ as a result of acid-catalyzed dissociation of the nitrophenol from the lanthanide. The nitrophenol group in Gd(NP-DO3AM) does not dissociate from the metal center even at $\mathrm{pH} 5$; therefore, the very modest increase in relaxivity in this complex must be ascribed to an increase in prototropic exchange rate of the bound water and/or phenolic protons.

\section{Introduction}

The use of paramagnetic metal complexes as contrast media in magnetic resonance imaging (MRI) is now widely accepted in diagnostic radiology. ${ }^{1-3}$ Agents currently approved for clinical use are based upon low-molecular weight chelates of gadolinium that partition throughout all extra cellular space and catalyze the relaxation of nearby water protons. Areas of regionally high contrast agent concentration are delineated by enhanced positive contrast in $T_{1}$-weighted MR images. The relaxivity, the increase in the rate of water proton relaxation rate 
per unit contrast agent, of all current clinical agents is $\sim 4 \mathrm{mM}^{-1} \mathrm{~s}^{-1}$. Much new developmental effort has focused on methods of improving relaxivity as a means of enhancing overall sensitivity of these nonspecific perfusion agents. Nonetheless, this family of agents has proven to be quite valuable even with a modest relaxivity. ${ }^{1,2}$ New paradigms for MR contrast agents will undoubtedly extend their utility to measures of $\mathrm{pH}$ changes or thermal variations. An elegant example of a potential next-generation functional imaging agent was described by Meade et al. ${ }^{4}$ In that work, a Gd(DO3A) derivative possessing a covalently linked $\beta$-galactose moiety was prepared in such a way as to block external coordination of water to the central gadolinium ion. Subsequent exposure to $\beta$-galactosidase cleaves the saccharide from the complex, opening up a vacant coordination site to allow water direct access to the gadolinium center. Exchange of coordinated water molecules with the bulk solvent is a primary mechanism by which these chelates catalyze water proton relaxation so that modulating the number of water molecules coordinated in the inner sphere will modulate the relaxivity, in this case in response to the presence of $\beta$-galactosidase.

Modulation of the hydration state, $q$, has been used to create agents that change relaxivity in response to $\mathrm{pH}$ and calcium and zinc ion concentrations. ${ }^{5-8}$ Lowe et al. employed a toluenesulfonamide as a $\mathrm{pH}$ labile ligating group in a $\mathrm{Gd}(\mathrm{DO} 3 \mathrm{~A})$ chelate $;^{5}$ as the $\mathrm{pH}$ of a solution is reduced, the sulfonamide becomes protonated and dissociates from the metal center. This increases the hydration state from $q=1$ to $q=2$, and a corresponding increase in relaxivity is observed. These authors also reported that careful consideration must be given to the ligating ability and $\mathrm{p} K_{\mathrm{a}}$ of the $\mathrm{pH}$ labile ligand to observe this effect. ${ }^{5,9}$ We have recently observed a similar $\mathrm{pH}$-sensitive dissociation in complexes with one $p$-nitrophenolic ligating group. The results of studies performed on the lanthanide(III) complexes of two ligands, the triacetate (NPDO3A) and triamide (NP-DO3AM) (Chart 1) are reported herein. These studies highlight the extent to which the choice of other ligating groups in the complex can affect the success of this type of responsive agent.

\section{Results and Discussion}

\section{Synthesis}

The ligand NP-DO3A was synthesized according to the route shown in Scheme 1.2Hydroxy-5-nitrobenzyl bromide was added to 2 equiv of cyclen in dioxane. Mono-alkylated cyclen was separated from di-substituted cyclens by column chromatography and residual cyclen removed by trituration of the mono-alkylated from chloroform. The acetates were then introduced into the mono-alkylated cyclen 1 using bromoacetic acid in water at $\mathrm{pH} 8.5$. After precipitation from acidified water, NP-DO3A was obtained in an overall yield of $27 \%$. The lanthanide complexes of NP-DO3A were synthesized from the corresponding lanthanide chloride in water at $\mathrm{pH} 4.5$.

Considering the low overall yield obtained in the synthesis of NP-DO3A, a different approach was taken in the synthesis of the triamide derivative, NP-DO3AM (Scheme 2). Here, three cyclen amines were first protected as tert-butoxycarbamates using di-tert-butyl dicarbonate.

${ }^{10}$ The remaining amine was then orthogonally protected as a benzyloxycarbamate using benzyl chloroformate. The mono-Cbz-protected cyclen $\mathbf{4}$ was obtained by removal of the Boc groups using methanolic hydrochloric acid. After liberation of the free base by base extraction, the three amines of 4 were alkylated with bromoacetamide, using standard conditions $\left(\mathrm{K}_{2} \mathrm{CO}_{3} /\right.$ $\mathrm{MeCN}$ ). DO3AM was obtained from the Cbz-protected DO3AM 5 by hydrogenolysis of the benzyloxycarbamate with $\mathrm{H}_{2}$ and $10 \%$ palladium on carbon. 2-Hydroxy-5-nitrobenzyl bromide was then used to alkylate the fourth nitrogen of DO3AM in ethanol, using $\mathrm{K}_{2} \mathrm{CO}_{3}$ as a base. After crystallization from methanol and acetonitrile the ligand NP-DO3AM was obtained in an overall yield of $48 \%$. The lanthanide complexes of NP-DO3AM were prepared 
from equimolar quantities of the ligand NP-DO3AM and either the lanthanide chloride or triflate at $60{ }^{\circ} \mathrm{C}$ in water.

\section{Crystal Structure}

An X-ray-quality crystal of the europium(III) salt of NP-DO3AM (Eu(NP-DO3AM)) was grown from aqueous solution ( $\mathrm{pH}$ 5) by slow evaporation at room temperature (see structure determination data in Table 1). The structure obtained by X-ray diffraction is shown in Figure 1. The complex crystallizes in the $P \bar{I}$ space group with two complexes, replete with coordinated water molecules, and four triflate counterions per unit cell. Since there are only two counterions per complex present in the unit cell, the overall formal charge of the complex is $2+$. This indicates that the phenol is deprotonated in this structure. The arrangement of donor atoms around the europium cation resembles that observed in crystal structures of other complexes of this type. The macrocycle adopts a [3333] conformation with each ethylene bridge adopting a gauche conformation (average $\mathrm{N}-\mathrm{C}-\mathrm{C}-\mathrm{N}$ torsion angle, $60.6^{\circ}$ ). The four nitrogen atoms of the macrocycle adopt a coplanar arrangement on one face of the europium ion. The four oxygen atoms of the pendant arms adopt a similar coplanar arrangement, sandwiching the europium ion. A water molecule caps the complex sitting above the plane of the oxygen atoms. The torsion angle between the $\mathrm{N}_{4}$ and $\mathrm{O}_{4}$ planes of $37^{\circ}$ defines the coordination geometry as a distorted monocapped square antiprism. Examination of the data (Table 2) reveals that a degree of distortion is present in the structure presumably the result of incorporation of the sixmembered chelate of the phenol. The europium-nitrogen, -amide oxygen and -water oxygen bond lengths are comparable with those reported for other tetraamide derivatives of DOTA. $11,12 \mathrm{The} \mathrm{Eu}-\mathrm{O}_{\text {phen }}$ bond distance is substantially shorter $(0.15 \AA)$ than the three $\mathrm{Eu}-\mathrm{O}_{\text {amide }}$ bonds, presumably reflecting the ionic nature of the phenoxide oxygen atom. The two triflate anions lie above the coordinated water molecule (Figure 1) with each triflate positioned such that a hydrogen bond from one triflate oxygen to one of the protons of coordinated water molecule is possible. The distances between the triflate oxygen and the water oxygen are 2.988 and $2.910 \AA$, respectively, consistent with hydrogen-bonding interactions. These conclusions are supported by the observations of Parker and co-workers who observed similar hydrogen bonding interactions with triflate anions in related tetraamide complexes. ${ }^{12}$

\section{Relaxivity Measurements}

The effect of $\mathrm{pH}$ upon the relaxivity of the two corresponding gadolinium complexes was examined at $25^{\circ} \mathrm{C}$ and $20 \mathrm{MHz}$ (Figure 2). The $\mathrm{pH}$ profile of Gd(NP-DO3A) shows a fairly substantial relaxivity enhancement $(71 \%)$ on passing from high to low $\mathrm{pH}$. This relaxivity enhancement was found to be reversible, and measurements repeated after incubation for 2 days confirmed that the enhancement was not the result of dissociation of the gadolinium ion. The relaxivity $\mathrm{pH}$ profile is noticeably different from that observed for Gd(DOTA) ${ }^{-}$which remains flat across this same $\mathrm{pH}$ range ${ }^{13}$ The form of the change is also radically different from that of $\mathrm{Gd}(\mathrm{DO} 3 \mathrm{~A})$ wherein the $\mathrm{pH}$ profile remains flat until below $\mathrm{pH} 4$ then, rises dramatically at lower $\mathrm{pH}$ values. ${ }^{13}$ Rather, the relaxivity enhancement observed for Gd(NPDO3A) is consistent with a $q=1$, anionic complex at high $\mathrm{pH}$ that becomes a $q=2$, neutral complex at low $\mathrm{pH}$ as the phenol becomes protonated and dissociates. The relaxivity observed at high $\mathrm{pH}\left(r_{1}=4.1 \mathrm{mM}^{-1} \mathrm{~s}^{-1}\right)$ is comparable with that of $\operatorname{Gd}($ DOTA $)-\left(r_{1}=4.2 \mathrm{mM}^{-1} \mathrm{~s}^{-1}\right)$ 14 and at low $\mathrm{pH}\left(r_{1}=7.0 \mathrm{mM}^{-1} \mathrm{~s}^{-1}\right)$ with that measured for $\operatorname{Gd}(\mathrm{DO} 3 \mathrm{~A})\left(r_{1}=6.9 \mathrm{mM}^{-1}\right.$ $\left.\mathrm{s}^{-1}\right)$.

An enhancement in the relaxivity of Gd(NP-DO3AM) was also observed at lower $\mathrm{pH}$ values, but in this case the enhancement was more modest, $\sim 25 \%$. The much smaller relaxivity enhancement observed for Gd(NP-DO3AM) is more difficult to understand in terms of phenol dissociation. The relaxivity value at high $\mathrm{pH}\left(r_{1}=2.8 \mathrm{mM}^{-1} \mathrm{~s}^{-1}\right)$ falls within the range expected 
for a dicationic, $q=1$ complex. ${ }^{11}$ The relaxivity at low $\mathrm{pH}\left(r_{1}=3.4 \mathrm{mM}^{-1} \mathrm{~s}^{-1}\right)$, however, falls short of that observed for the $q=2 \mathrm{Gd}(\mathrm{DO} 3 \mathrm{AM})^{3+}\left(r_{1}=4.7 \mathrm{mM}^{-1} \mathrm{~s}^{-1}, \mathrm{pH} 4\right.$ and 9).

The relaxivity $\mathrm{pH}$ profiles in Figure 2 were fitted to a simple protonation equilibrium (eq 1). The $\mathrm{p} K_{\mathrm{a}}$ value of $\mathrm{Gd}(\mathrm{NP}-\mathrm{DO} 3 \mathrm{~A})$ was determined by potentiometric titration at $7.36( \pm 0.04)$, and a good fit for the data was obtained using this value. In contrast the $\mathrm{p} K_{\mathrm{a}}$ value determined by potentiometric titration for $\mathrm{Yb}(\mathrm{NP}-\mathrm{DO} 3 \mathrm{AM})$ was significantly lower $7.22( \pm 0.05)$.

However, this value does not readily allow the relaxivity data to be fitted, in fact an apparent $\mathrm{p} K_{\mathrm{a}}$ value of 6.48 is obtained for $\mathrm{Gd}(\mathrm{NP}-\mathrm{DO} 3 \mathrm{AM})$ when the relaxivity data are fitted to eq 1.

$$
K_{a}=\frac{[\mathrm{GdLH}]}{\left[\mathrm{GdL}^{-}\right]\left[\mathrm{H}^{+}\right]}
$$

That the $\mathrm{p} K_{\mathrm{a}}$ values of $\mathrm{Ln}(\mathrm{NP}-\mathrm{DO} 3 \mathrm{AM})$ complexes are lower than those of the corresponding acetate analogues may easily be rationalized in terms of the electron-donating ability of the other pendant arms in the complex. Acetates are ionic electron donors and therefore much more effective electron donors than the nonionic amides. Given the increased electron donation to the central lanthanide in $\operatorname{Ln}(\mathrm{NP}-\mathrm{DO} 3 \mathrm{~A})$ complexes, it is expected that the lanthanide will be less electron deficient in these complexes than in the corresponding Ln(NP-DO3AM) complexes. Ln(NP-DO3A) complexes will therefore have less demand for electron density from the phenolic group, raising the $\mathrm{p} K_{\mathrm{a}}$ of the phenolic proton This, in part, accounts for the higher $\mathrm{pH}$ range over which the relaxivity is enhanced for Gd(NP-DO3A). However, it is apparent that a difference in the mechanism by which these two complexes enhance relaxivity exists. The relaxivity enhancement of Gd(NP-DO3A) occurs as the phenolic group is being protonated, whereas the enhancement observed for Gd(NP-DO3AM) occurs at below the $\mathrm{pH}$ at which the phenol is protonated. We postulate that the origin of this difference in mechanism is also the result of differences in the electron-donating ability of the other ligating groups present in these two complexes.

\section{Luminescence and NMR Measurements}

Lanthanide-based luminescence is an invaluable tool for probing the structure and behavior of lanthanide complexes, giving information on the extent of hydration, interactions with cations and anions, as well as structural and electronic aspects of a complex. Luminescence is especially useful for measuring the hydration state, $q$, of lanthanide complexes using Horrocks' method ${ }^{15,16}$ or a modified method reported by Parker and co-workers. ${ }^{17}$ The intensity of lanthanide-based luminescent emission may often be enhanced by excitation of the lanthanide ion via a sensitizing chromophore. However, the $p$-nitrophenol substituent proves to be a hindrance rather than a help in this regard. Europium and terbium are the most commonly studied lanthanide ions due to their long-lived excited states. But, due to the comparative ease with which the $\mathrm{Eu}^{3+}$ ion may be reduced $\left(E_{\mathrm{Ox}} \approx 0.8 \mathrm{~V}\right.$ ) the study of europium by luminescence in this case was not feasible. Cyclic voltammograms of Gd(NP-DO3AM) over the $\mathrm{pH}$ range 4.1-7.6 show that the first oxidation of the $p$-nitrophenol moiety occurs at $128 \mathrm{mV}$ (referenced to $\mathrm{Ag} / \mathrm{AgCl}$ ) and is insensitive to $\mathrm{pH}$. Thus ligand-metal charge transfer (LMCT) from the readily oxidized $p$-nitrophenol group rapidly quenches the excited state of the $\mathrm{Eu}^{3+}$ ion. Europium-based emission in these ligands is so weak that a study of these complexes was precluded. This limited study to the $\mathrm{Tb}^{3+}$ complexes.

Nonradiative deactivation of the excited state of terbium by proximate $\mathrm{OH}$ oscillators causes some quenching of luminescent emission. The more $\mathrm{OH}$ oscillators present the greater the extent of this quenching effect, and so lanthanides with more coordinated water molecules will have shorter luminescent lifetimes. The lifetime of terbium-based emission measured for $\mathrm{Tb}$ $(\mathrm{NP}-\mathrm{DO} 3 \mathrm{~A})\left(\lambda_{\mathrm{ex}}=270 \mathrm{~nm}, \lambda_{\mathrm{em}}=545 \mathrm{~nm}\right)$ at high $\mathrm{pH}$ was around twice as long as that measured 
at low pH (Figure 3). This observation is consistent with a change in the number of proximate $\mathrm{OH}$ oscillators with changing $\mathrm{pH}$. However, an increase in the number of proximate $\mathrm{OH}$ oscillators is not the only mechanism by which a change in emission intensity may be observed as a function of changing $\mathrm{pH}$. If the energy gap between the triplet energy level of an adjacent aromatic chromophore and the terbium excited state $\left({ }^{5} \mathrm{D}_{4}\right)$ is very small, then energy may not only pass from the chromophore to terbium ion but also back again. This back energy transfer (BET) will result in an increase in ligand-based emission at the expense of terbium-based emission. The lifetimes recorded for $\mathrm{Tb}(\mathrm{NP}-\mathrm{DO} 3 \mathrm{~A})$ at both low and high $\mathrm{pH}\left(\tau_{\mathrm{Tb}}=0.25-0.58\right.$ $\mathrm{ms}$ ) are considerably shorter than those observed for other terbium complexes (typical lifetimes are $\tau_{\mathrm{Tb}} \approx 1.0 \mathrm{~ms}$ for $q=3$ complexes and $\sim 3.0 \mathrm{~ms}$ for $q=0$ complexes). ${ }^{17}$ Such short luminescent lifetimes suggest that another nonradiative decay mechanism takes place in this system besides the vibronic quenching of $\mathrm{OH}$ oscillators. To investigate this further, the triplet energy level of $\mathrm{Gd}\left(\mathrm{NP}-\mathrm{DO} 3 \mathrm{~A}\right.$ ) was measured at $77 \mathrm{~K}$. At pH 4.0 the $T_{1}$ energy level lies some 2000 $\mathrm{cm}^{-1}$ above the ${ }^{5} \mathrm{D}_{4}$ state of $\mathrm{Tb}$ and $1800 \mathrm{~cm}^{-1}$ higher at $\mathrm{pH} 8.3$ (Figure 4). An energy gap of this size is small enough to allow a considerable amount of BET, hence, the shorter than expected luminescent lifetimes. ${ }^{18}$ However, since no substantial change in the triplet energy level is observed with $\mathrm{pH}$ and the change in lifetime mirrors the relaxivity profile of Gd(NPDO3A), it seems likely that a change in the number of $\mathrm{OH}$ oscillators is related to the relaxation switching effect. This is further supported by the observation that the $\mathrm{pH}$ range over which terbium emission decreases is identical to that over which the relaxivity is enhanced.

In contrast to the observation for $\mathrm{Tb}$ (NP-DO3A), when the terbium-based luminescence of $\mathrm{Tb}$ (NP-DO3AM) was measured as a function of $\mathrm{pH}$, the intensity of emission was found to drop rapidly with rising $\mathrm{pH}$ until at $\mathrm{pH} 7$ almost no emission intensity could be detected. This trend is the reverse of that observed for $\mathrm{Tb}(\mathrm{NP}-\mathrm{DO} 3 \mathrm{~A})$; it is also a much more dramatic change and one which cannot be explained by changes in the hydration state of $\mathrm{Tb}^{3+}$. Measurement of the triplet energy level of Gd(NP-DO3AM) at $77 \mathrm{~K}$ indicates a smaller energy gap, $1700 \mathrm{~cm}^{-1}$ at $\mathrm{pH}$ 4.1. However, this energy gap closes as the $\mathrm{pH}$ rises until at $\mathrm{pH} 7.0$ the gap is just 500 $\mathrm{cm}^{-1}$ (Figure 4). Such a small gap increases the extent of BET thereby, quenching nearly all of the terbium-based luminescent intensity. Since the luminescent lifetime of Tb(NP-DO3AM) at high $\mathrm{pH}$ is so short, accurate measurement is not feasible. Thus, measuring the hydration state of the complexes by Horrocks' method is not viable.

In light of the BET inherent in the luminescent behavior of the terbium complexes a second method of determining the hydration state was employed. The contact shift arising from exchange of water molecules coordinated to $\mathrm{Dy}^{3+}$ gives rise to a shift in the bulk water resonance in the ${ }^{17} \mathrm{O}$ NMR spectrum. The hydration state may be determined by monitoring the dysprosium-induced shift of the bulk water resonance as a function of the concentration of the dysprosium complex. ${ }^{19}$ The hydration states of Dy(NP-DO3A) and Dy(NP-DO3AM) were determined under both basic and acidic conditions (Supporting information). As anticipated, the hydration state of Dy(NP-DO3A) at $\mathrm{pD} 4$ was determined to be 1.8 , whereas at $\mathrm{pD} 9$ the value of $q$ was 0.92 . In contrast, the hydration state of Dy(NP-DO3AM) does not vary significantly between the two $\mathrm{pHs}$, with values of $q=1.1$ and 1.2 being determined at $\mathrm{pD} 4$ and 9 , respectively. These results help us understand the origin of the relaxivity enhancement in each complex.

In the case of Gd(NP-DO3A) an increase in proton concentration results in protonation of the phenoxide oxygen with subsequent dissociation of the phenolic pendant arm from the metal center. This vacates a coordination site, thereby allowing coordination of a second water molecule and an increase in relaxivity. Thus, the relaxivity enhancement closely correlates with the $\mathrm{p} K_{\mathrm{a}}$ of the phenol. The origin of the relaxivity enhancement observed for Gd(NPDO3AM) is more difficult to pin down, but the dissociation of the nitrophenol pendant arm from the metal center can be ruled out. Of course, exchange of coordinated water molecules 
with the bulk solvent is not the only means by which inner sphere relaxivity may be effected. It is sufficient that only protons in the inner sphere exchange with the bulk; thus, a change in the number of exchangeable protons on the complex, or in the rate that they exchange, would be sufficient to effect a change in relaxivity. More slowly exchanging systems may be probed by the use of saturation transfer NMR experiments. In an attempt to identify any site that may be in slow exchange, saturation transfer experiments were performed in $\mathrm{H}_{2} \mathrm{O}$, at $0{ }^{\circ} \mathrm{C}$ presaturating at increments across the frequency range from +60 to $-60 \mathrm{ppm}$. The effect of presaturation upon the intensity of the bulk water signal was monitored, any decrease in bulk water intensity being indicative of a two-pool exchange process. At both low and high $\mathrm{pH}$ (4 and 9) no saturation transfer effects were observed, suggesting that a change from a slowexchange regime was not involved in the relaxivity enhancement mechanism.

The fact that the relaxivity enhancement of Gd(NP-DO3AM) does not directly correspond to a $\mathrm{p} K_{\mathrm{a}}$ in the complex may, however, hold a clue to the origin of the relaxivity change. By plotting the relaxivity profile of Gd(NP-DO3AM) alongside the data from the potentiometric titration (Figure 5) it can be seen that the $\mathrm{p} K_{\mathrm{a}}$ of $7.22( \pm 0.05)$ determined from the potentiometric titration lies close to the onset of the relaxivity enhancement. We can imagine that around its $\mathrm{p} K_{\mathrm{a}}$ value the oxygen of the phenol, which remains coordinated to the metal center, is transiently protonated; that is to say that, although the phenol is protonated, the protons are in extremely rapid exchange with the bulk solvent and do not reside on the complex long enough to be efficiently relaxed. As the $\mathrm{pH}$ is lowered further, the rate of this exchange slows down to such an extent that the protons reside on the complex long enough for relaxation by gadolinium to occur before they are replaced. In this way the protonated phenol pendant arm begins to contribute to the overall relaxivity of the complex through prototopic exchange but only at $\mathrm{pH}$ values below the $\mathrm{p} K_{\mathrm{a}}$ of the phenol. Once the rate of prototopic exchange in the complex plateaus, so does the relaxivity enhancement. The similarity of this $\mathrm{p} K_{\mathrm{a}}$ value (7.22) with that of the phenol in Gd(NP-DO3A) (7.36) leads us to conclude that the observed $\mathrm{p} K_{\mathrm{a}}$ is that of the phenol. Deprotonation of the phenol improves the electron-donating capacity of the phenol in this complex which in turn appears to substantially raise the $\mathrm{p} K_{\mathrm{a}}$ of the coordinated water molecule. The $\mathrm{p} K_{\mathrm{a}}$ of the coordinated water molecule in $\mathrm{Yb}(\mathrm{NP}-\mathrm{DO} 3 \mathrm{AM})$ was determined to be $10.20( \pm 0.04)$, substantially higher than the value of 7.90 determined for tricationic tetraamide complexes by Parker and co-workers. ${ }^{11}$ In this respect it is expected that prototopic exchange of the water protons are not significantly involved in the mechanism of relaxivity enhancement for this complex. The differences in the magnitude and $\mathrm{pH}$ of the relaxivity enhancements observed for these two complexes can readily be accounted for by the radical change in mechanism observed when the nature of other ligating groups in the chelate are altered.

\section{Effect of Endogenous Anions and Complex Stability}

The decidedly small relaxivity enhancement observed for Gd(NP-DO3AM) means that this complex has less viability as a contrast agent for MR imaging. The more substantial increase observed for Gd(NP-DO3A) on the other hand could render this a useful basis for the design of a practical responsive MR imaging agent. However, one feature of lanthanide complexes in which two coordination sites of the metal ion are available for water molecules is that they can bind endogenous anions, displacing the inner sphere water molecules. ${ }^{18,20-23}$ Clearly such binding is undesirable since it results in a lowering of relaxivity and perturbation of the inflection point. To assess the effect of endogenous anions upon the relaxivity, $1 \mathrm{mM}$ solutions of Gd(NP-DO3A) were titrated against citrate, acetate, lactate, and phosphate at both $\mathrm{pH} 4$ and 9. In the presence of up to 40 equiv of each anion, no effect upon relaxation rate was observed, suggesting that none of these endogenous anions bind to the complex in either the $q=1$ or $q$ $=2$ hydration states (Supporting Information). Although not measured here, the effect of carbonate binding has also been reported to have deleterious effects upon relaxivity. 5,18 
However, the effects of carbonate are unlikely to represent a serious drawback to the use of Gd(NP-DO3A) in vivo since the carbonates are only observed to bind in a bidentate manner. Thus, carbonate is only likely to affect the complex at lower $\mathrm{pH}$ when the phenolic pendant arm has dissociated; however, the amount of bicarbonate in solution diminishes as the $\mathrm{pH}$ is lowered. Recently, Parker and co-workers described an elegant solution to bicarbonate binding that could easily be incorporated into this chelate. ${ }^{24}$ The onset of carbonate binding was found to be prevented by incorporating anionic substituents into the chelate to leave it formally negatively charged.

One further consideration as to whether a complex may be used in vivo is the stability of the complex. In this regard good kinetic stability is a more important feature of a complex than thermodynamic stability. This is because ultimately it is only important that the rate of complex dissociation is slow enough that the complex is excreted from the body before dissociation occurs. Octadentate ligands such as DOTA and HP-DO3A form extremely kinetically and thermodynamically stable complexes with gadolinium, and it is reasonable to assume that in octadentate form, NP-DO3A will also form highly stable complexes. However, under acidic conditions NP-DO3A becomes a heptadentate ligand, and such ligands are generally known to be less kinetically inert than their octadentate counterparts. Since the demetalation of these complexes is believed to be a cation-mediated process, usually via protons or $\mathrm{Zn}^{2+}$ ions, the kinetic stability of the complex was assessed by examining the extent of dissociation induced by the presence of these two cations. Accordingly, a solution of ${ }^{177} \mathrm{Lu}(\mathrm{NP}-\mathrm{DO} 3 \mathrm{~A})$ was synthesized using a 5-fold excess of ligand. After verification that better than $98 \%$ of the lanthanide ion had been complexed, aliquots of the solution were taken and adjusted to different $\mathrm{pH}$ values over the range $1-11$. After incubation, the amount of ${ }^{177} \mathrm{Lu}$ liberated from the complex after $5 \mathrm{~min}, 2 \mathrm{~h}, 6 \mathrm{~h}$, and $24 \mathrm{~h}$ was determined at each $\mathrm{pH}$ point by eluting a sample through a Sephadex G-50 column. The radioactivities of the eluent and the column were then compared. The intact complex elutes, but free lutetium is retained by the column, so that by comparing the radioactivity of the two the percentage of free lutetium present may be determined. The results (Figure 6) show unequivocally that lanthanide complexes of NP-DO3A are kinetically inert over a $\mathrm{pH}$ range from 4 to 11 . At lower $\mathrm{pH}$ values $(\mathrm{pH} 1-3)$ dissociation of the lutetium ion is observed. The extent of dissociation does not alter significantly as a function of time, suggesting that the equilibrium position is achieved rapidly. A similar technique was used to assess the effect of $\mathrm{Zn}^{2+}$ upon the kinetic stability of the complex. A 1 $\mathrm{mM}$ solution of ${ }^{177} \mathrm{LuNP}-\mathrm{DO} 3 \mathrm{~A}$ was prepared using a 3-fold excess of the ligand. The $\mathrm{pH}$ was adjusted to 7.4 and $\mathrm{ZnCl}_{2}$ added such that the solution was $3 \mathrm{mM}$ in zinc. The solution was incubated for $24 \mathrm{~h}$, and aliquots were removed after $5 \mathrm{~min}, 2 \mathrm{~h}, 16 \mathrm{~h}$, and $24 \mathrm{~h}$. The extent of complex dissociation measured using the method described above. Over the course of the experiment the extent of demetalation by $\mathrm{Zn}^{2+}$ was found to be less than $2 \%$. The stability over such a wide $\mathrm{pH}$ range and in response to $\mathrm{Zn}^{2+}$ ions suggests that the lanthanide complexes of NP-DO3A should exhibit favorable in vivo stabilities.

\section{Conclusions}

We have successfully demonstrated that a methylene nitro-phenol pendant arm may be employed as a pH-responsive pendant arm in DO3A-type complexes. The $\mathrm{pH}$ range over which this pendant arm dissociates from the central lanthanide ion renders it ideal as the basis of new pH-responsive contrast media for MRI. In addition, the relaxivity profile of Gd(NP-DO3A) appears to be unaffected by endogenous anions, and the complex is found to be inert to demetalation over the $\mathrm{pH}$ range $2-11$ and in response to $\mathrm{Zn}^{2+}$ ions. Substitution of amide pendant arms for acetates has several deleterious effects on the complex. The reduced electrondonating capacity of the amide-ligating groups renders the central lanthanide ion too electron deficient to release the nitrophenol. In consequence, the relaxivity enhancement of [ $\mathrm{Gd}(\mathrm{NP}-$ 
DO3AM)] is rather modest and appears to arise from prototopic exchange of the phenolic proton as it becomes protonated at lower $\mathrm{pH}$.

\section{Experimental Section}

\section{General Remarks}

All solvents and reagents were purchased from commercial sources and used as received. ${ }^{1} \mathrm{H}$ and ${ }^{13} \mathrm{C}$ NMR spectra were recorded on a JEOL Eclipse 270 spectrometer at 270.17 and 67.93 $\mathrm{MHz}$, respectively, or on a Bruker Avance spectrometer at 250.13 and $62.89 \mathrm{MHz}$, respectively. ${ }^{17} \mathrm{O}$ NMR spectra were recorded on a Varian Inova 500 spectrometer operating 67.72 MHz. Relaxation measurements were made using an MRS-6 NMR Analyzer from the Institut “Jožef Stefan”, Ljubljana, Slovenjia, operating at $20 \mathrm{MHz}$. Luminescence spectra were recorded on a Perkin-Elmer LS55 or an Edinburgh Instruments nF 900 fluorimeter. The $\mathrm{pH}$ of luminescence samples were measured using a Fisher Accumet $925 \mathrm{pH}$ meter equipped with an Orion 8103 Ross combination $\mathrm{pH}$ electrode. The $\mathrm{pH}$ of luminescence samples was altered by addition of solid lithium hydroxide monohydrate or $p$-toluenesulfonic acid. Triplet energy levels were determined from the measured emission spectra of frozen samples of the corresponding gadolinium(III) complex at $77 \mathrm{~K}$. Singlet energy levels were obtained by comparing the excitation spectra and the absorption spectra of the complexes recorded on a Hewlett-Packard 8453 UV-visible spectrometer. Cyclic voltammograms were recorded on a BAS CV-50W voltammetric analyzer using a glassy carbon working electrode, platinum wire auxiliary electrode, and $\mathrm{Ag} / \mathrm{AgCl}$ reference electrode. Samples were prepared at $0.6 \mathrm{mM}$ concentrations using a $50 \mathrm{mM}$ solution of tetrabutylammonium perchlorate in acetonitrile and a buffer solution of either phosphate-citrate or tris buffer.

\section{1-Methlyene-( $p$-nitrophenol)-1,4,7,10-tetraazacyclododecane (1)}

To a stirred dioxane solution ( $20 \mathrm{~mL})$ of 1,4,7,10-tetraazacyclododecane (2.3 g, $14.0 \mathrm{mmol})$ was added a solution of 2-hydroxy-5-nitrobenzyl bromide $(1.2 \mathrm{~g}, 7.0 \mathrm{mmol})$ in dioxane (15 $\mathrm{mL})$. After $5 \mathrm{~min}, \mathrm{~K}_{2} \mathrm{CO}_{3}(1 \mathrm{~g}, 7.2 \mathrm{mmol})$ was added and the reaction stirred for $1 \mathrm{~h}$ at ambient temperature. The reaction mixture was then filtered and the filtrate concentrated in vacuo to give a yellow semisolid which was purified by column chromatography over silica gel eluting with $\mathrm{CHCl}_{3} / \mathrm{MeOH} / \mathrm{NH}_{4} \mathrm{OH}$ (3:2:1). The title compound was isolated from the slower-moving yellow fraction which also contained cyclen starting material. The resulting yellow oil was triturated with $\mathrm{CHCl}_{3}(100 \mathrm{~mL})$ to remove cyclen and filtered to afford the title compound as a crystalline yellow solid $(1.2 \mathrm{~g}, 55 \%): \mathrm{mp} 142-145^{\circ} \mathrm{C} .{ }^{1} \mathrm{H}$ NMR $(250 \mathrm{MHz}, \mathrm{D} 2 \mathrm{O}): \delta=7.84$ (2H, m, 4-Ph,6-Ph), 6.30 (1H m, 3-Ph), 3.39 (2H, s, NCH $\mathrm{N}_{2} \mathrm{Ar}$ ), 2.70-2.87 (16H, m br, ring $\left.\mathrm{CH}_{2}\right) .{ }^{13} \mathrm{C}$ NMR $\left(62.9 \mathrm{MHz}, \mathrm{D}_{2} \mathrm{O}\right): \delta=45.3\left(\right.$ ring $\left.\mathrm{CH}_{2}\right), 45.5\left(\right.$ ring $\left.\mathrm{CH}_{2}\right), 47.2\left(\right.$ ring $\left.\mathrm{CH}_{2}\right), 51.7$ (ring $\mathrm{CH}_{2}$ ), $56.3\left(\mathrm{NCH}_{2} \mathrm{Ar}\right), 122.0$ (4-Ph), 128.3 (5-Ph), 130.9 (6-Ph), 131.9 (1-Ph), 135.6 (3$\mathrm{Ph}), 180.1$ (2-Ph). $v_{\max } / \mathrm{cm}^{-1}: 3356$ br (NH/OH), 2994, 2957, 2849, 1588, 1472, 1460, 1434, $1273,1241,1168,1132,1086$. HRMS (MALDI): $\mathrm{C}_{15} \mathrm{H}_{26} \mathrm{~N}_{5} \mathrm{O}_{3}\left([\mathrm{MH}]^{+}\right.$) requires 324.2037, found 324.2033 .

\section{1-Methlyene-(p-nitrophenol)-1,4,7,10-tetrazacyclododecane-4,7,10-triacetic Acid (NP-DO3A)}

The mono-alkylated cyclen $(\mathbf{1})(0.2 \mathrm{~g}, 0.6 \mathrm{mmol})$ was dissolved in water $(5 \mathrm{~mL})$ and the $\mathrm{pH}$ adjusted to 5 using $\mathrm{HCl}(12 \mathrm{~N})$. A solution of bromoacetic acid $(309 \mathrm{mg}, 2.2 \mathrm{mmol})$ in water $(10 \mathrm{~mL})$ was added in one portion and the $\mathrm{pH}$ adjusted to and maintained at 8.5 by addition of $45 \% \mathrm{KOH}$ solution. Once the $\mathrm{pH}$ was stabilized at 8.5 for $1 \mathrm{~h}$, the $\mathrm{pH}$ was raised to 11 and maintained for $6 \mathrm{~h}$. The solution was then cooled in an ice bath and acidified to $\mathrm{pH} 2$ with concentrated $\mathrm{HCl}$. A saturated solution of $\mathrm{KCl}$ was then added to facilitate crystallization of the desired product. After stirring for $1 \mathrm{~h}$ the colorless precipitate was filtered and dried in vacuo to afford the title compound as a colorless solid (150 mg, 49\%): $\mathrm{mp} 230-235^{\circ} \mathrm{C}$ dec. ${ }^{1} \mathrm{H}$ NMR (250 MHz, $\left.\mathrm{D}_{2} \mathrm{O}\right): \delta=7.87$ (2H, m, Ph-4, Ph-6), $6.38(1 \mathrm{H}, \mathrm{m}, \mathrm{Ph}-3), 3.39(2 \mathrm{H}$, 
s, $\left.\mathrm{NCH}_{2} \mathrm{Ar}\right), 3.01-2.90\left(16 \mathrm{H}, \mathrm{m}\right.$ br, ring $\left.\mathrm{CH}_{2}\right), 2.74\left(2 \mathrm{H}, \mathrm{s}, \mathrm{NCH}_{2} \mathrm{CO}_{2}\right), 2.67(4 \mathrm{H}, \mathrm{s}$, $\left.\mathrm{NC}_{\mathrm{H} 2} \mathrm{CO}_{2}\right) .{ }^{13} \mathrm{C}$ NMR $\left(62.9 \mathrm{MHz}, \mathrm{D}_{2} \mathrm{O}\right): \delta=51.3\left(\right.$ ring $\left.\mathrm{CH}_{2}\right), 55.0\left(\right.$ ring $\left.\mathrm{CH}_{2}\right), 55.4$ (ring $\left.\mathrm{CH}_{2}\right), 58.3\left(\mathrm{NCH}_{2} \mathrm{CO}_{2}\right), 60.6\left(\mathrm{NCH}_{2} \mathrm{CO}_{2}\right), 62.1\left(\mathrm{NCH}_{2} \mathrm{Ar}\right), 121.2(4-\mathrm{Ph}), 128.4(5-\mathrm{Ph}), 130.6$ (6-Ph), $132.9(1-\mathrm{Ph}), 137.5(3-\mathrm{Ph}), 175.5(2-\mathrm{Ph}), 182.1(\mathrm{C}=\mathrm{O}), 183.4(\mathrm{C}=\mathrm{O}) \cdot v_{\max } / \mathrm{cm}^{-1}: 3378$ br $(\mathrm{OH}), 3075,2961,2861,1717(\mathrm{C}=\mathrm{O}), 1595,1526,1456,1395,1341,1288,1234,1094$. HRMS (MALDI) $\mathrm{C}_{21} \mathrm{H}_{32} \mathrm{~N}_{5} \mathrm{O}_{9}\left([\mathrm{MH}]^{+}\right)$requires 498.2202, found 498.2180 .

\section{1,4,7-Tris-tert-butoxycarbonyl-1,4,7,10-tetraazacyclododecane (2). ${ }^{10}$}

A solution of di-tert-butyl dicarbonate $(23.0 \mathrm{~g}, 106 \mathrm{mmol})$ in chloroform $(130 \mathrm{~mL})$ was added dropwise over the course of $2 \mathrm{~h}$ to a solution of cyclen $(6.0 \mathrm{~g}, 35 \mathrm{mmol})$ and triethylamine $(15$ $\mathrm{mL}, 106 \mathrm{mmol})$ in chloroform $(170 \mathrm{~mL})$ at $0{ }^{\circ} \mathrm{C}$. The resulting solution allowed to warm to room temperature and stirred for $18 \mathrm{~h}$. The reaction mixture was then washed with water $(2 \times$ $100 \mathrm{~mL}$ ), the organic layer was dried over $\mathrm{Na}_{2} \mathrm{SO}_{4}$, and the solvents were removed in vacuo. The residue was purified by column chromatography over a silica gel eluting with diethyl ether to afford the title compound as a colorless solid $(14.8 \mathrm{~g}, 90 \%) \cdot R_{f}=0.3\left(\mathrm{SiO}_{2}, \mathrm{Et}_{2} \mathrm{O}\right) . \mathrm{Mp}=$ $72-73.5{ }^{\circ} \mathrm{C} .{ }^{1} \mathrm{H}$ NMR $\left(270 \mathrm{MHz}, \mathrm{CDCl}_{3}\right): \delta=3.50\left(4 \mathrm{H}\right.$, s br, ring $\left.\mathrm{CH}_{2}\right), 3.15(8 \mathrm{H}$, s br, ring $\left.\mathrm{CH}_{2}\right), 2.71\left(4 \mathrm{H}, \mathrm{s}\right.$ br, ring $\left.\mathrm{CH}_{2}\right), 1.33\left(9 \mathrm{H}, \mathrm{s}, \mathrm{C}\left(\mathrm{CH}_{3}\right)_{3}\right), 1.31\left(18 \mathrm{H}, \mathrm{s}, \mathrm{C}\left(\mathrm{CH}_{3}\right)_{3}\right) .{ }^{13} \mathrm{C} \mathrm{NMR}$

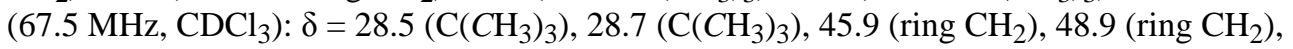

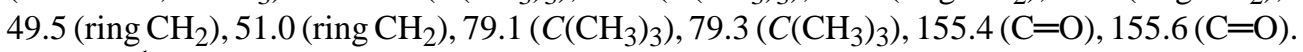
$v_{\max } / \mathrm{cm}^{-1}: 3312(\mathrm{NH}), 2976,2932,2815,1690(\mathrm{C}=\mathrm{O}), 1463,1417,1365,1248,1172,1088$, 774. $\mathrm{m} / \mathrm{z}(\mathrm{ESI}+) ; 473\left(100 \%[\mathrm{M}+\mathrm{H}]^{+}\right), 495\left(5 \%[\mathrm{M}+\mathrm{Na}]^{+}\right)$. Anal. Found $\mathrm{C}=58.3 \%, \mathrm{H}=$ $9.7 \%, \mathrm{~N}=11.7 \%$. $\mathrm{C}_{23} \mathrm{H}_{44} \mathrm{~N}_{4} \mathrm{O}_{6}$ requires $\mathrm{C}=58.5 \%, \mathrm{H}=9.3 \%, \mathrm{~N}=11.9 \%$.

\section{1-Benzyloxycarbonyl-4,7,10-tris-tert-butoxycarbonyl-1,4,7,10-tetraazacyclododecane (3)}

To a cooled solution $\left(0{ }^{\circ} \mathrm{C}\right)$ of the tri-Boc-protected cyclen $2(6.6 \mathrm{~g}, 14.0 \mathrm{mmol})$ and triethylamine $(2.4 \mathrm{~mL}, 16.7 \mathrm{mmol})$ in chloroform $(150 \mathrm{~mL})$ was added benzyl chloroformate $(2.9 \mathrm{~g}, 16.7 \mathrm{mmol})$. The resulting solution was allowed to warm to room temperature and stirred for $8 \mathrm{~h}$. The precipitates were removed by filtration, and the solvents were removed in vacuo. The residue was purified by column chromatography over silica gel eluting with $30 \%$ ethyl acetate in hexanes to afford the title compound as a colorless solid $(8.3 \mathrm{~g}, 98 \%) . R_{f}=0.5$ $\left(\mathrm{SiO}_{2}, 30 \%\right.$ EtOAc hexanes $) . \mathrm{Mp}=76.5-77.5^{\circ} \mathrm{C} .{ }^{1} \mathrm{H} \mathrm{NMR}\left(270 \mathrm{MHz}, \mathrm{CDCl}_{3}\right): \delta=7.28(5 \mathrm{H}$, $\mathrm{m}, \mathrm{Ph}), 5.04\left(2 \mathrm{H}, \mathrm{s}, \mathrm{OCH}_{2} \mathrm{Ph}\right), 3.44\left(6 \mathrm{H}, \mathrm{s} \mathrm{br}, \mathrm{NCH}_{2} \mathrm{CO}\right), 3.32\left(16 \mathrm{H}, \mathrm{m} \mathrm{br}\right.$, ring $\left.\mathrm{CH}_{2}\right), 1.38$ $\left(9 \mathrm{H}, \mathrm{s}, \mathrm{C}\left(\mathrm{CH}_{3}\right)_{3}\right), 1.35\left(18 \mathrm{H}, \mathrm{s}, \mathrm{C}\left(\mathrm{CH}_{3}\right)_{3}\right) .{ }^{13} \mathrm{C} \mathrm{NMR}\left(67.5 \mathrm{MHz}, \mathrm{CDCl}_{3}\right): \delta=28.4(\mathrm{C}$

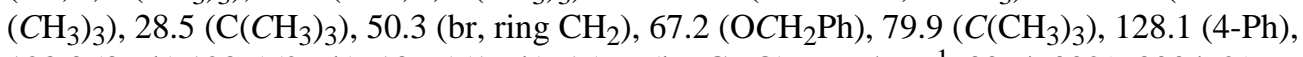
$128.3(3-\mathrm{Ph}) 128.5(2-\mathrm{Ph}), 136.5(1-\mathrm{Ph}), 156.6$ (br, C=O). $v_{\max } / \mathrm{cm}^{-1}: 3064,3029,3004,2976$, $2933,1694(\mathrm{C}=\mathrm{O}), 1468,1411,1366,1248,1165,1102,1028,776$. A suitable analysis of this compound could not be obtained.

\section{1-Benzyloxycarbonyl-1,4,7,10-tetraazacyclododecane Trihydrochloride (4)}

To a cooled solution $\left(0^{\circ} \mathrm{C}\right)$ of the protected cyclen $3(8.0 \mathrm{~g}, 13.2 \mathrm{mmol})$ in methanol $(10 \mathrm{~mL})$ was added concentrated $\mathrm{HCl}(10 \mathrm{~mL})$ dropwise. The resulting solution was allowed to warm to room temperature and stirred for $8 \mathrm{~h}$. The reaction was concentrated at room temperature under reduced pressure to a volume of $15 \mathrm{~mL}$, and the precipitates were removed by filtration. The residue was then crystallized from a mixture of water and tetrahydrofuran to afford the title compound as a colorless crystalline solid $(5.1 \mathrm{~g}, 94 \%) . \mathrm{Mp}=191.5-192.5^{\circ} \mathrm{C} .{ }^{1} \mathrm{H}$ NMR $\left(270 \mathrm{MHz}, \mathrm{CD}_{3} \mathrm{OD}\right): \delta=7.40(5 \mathrm{H}, \mathrm{m}, \mathrm{Ph}), 5.15\left(2 \mathrm{H}, \mathrm{s}, \mathrm{OCH}_{2} \mathrm{Ph}\right), 3.14(16 \mathrm{H}, \mathrm{m}$, ring $\left.\mathrm{CH}_{2}\right) .{ }^{13} \mathrm{C}$ NMR $(67.5 \mathrm{MHz}, \mathrm{CD} 3-\mathrm{OD}): \delta=43.0\left(\right.$ ring $\left.\mathrm{CH}_{2}\right), 44.7\left(\right.$ ring $\left.\mathrm{CH}_{2}\right), 45.4$ (ring $\left.\mathrm{CH}_{2}\right), 46.7$ (ring $\left.\mathrm{CH}_{2}\right), 68.8\left(\mathrm{OCH}_{2} \mathrm{Ph}\right), 128.5(3-\mathrm{Ph}), 128.9$ (4-Ph), $129.0(2-\mathrm{Ph}), 135.8$ (1$\mathrm{Ph}), 158.5(\mathrm{C}=\mathrm{O}) \cdot v_{\max } / \mathrm{cm}^{-1}: 3430(\mathrm{NH}), 2997,2806,1709(\mathrm{C}=\mathrm{O}), 1622,1447,1261,1162$, 767, 741. $\mathrm{m} / \mathrm{z}(\mathrm{ESI}+) ; 307\left(100 \%[\mathrm{M}+\mathrm{H}]^{+}\right), 329\left(3 \%[\mathrm{M}+\mathrm{Na}]^{+}\right)$. Anal. Found $\mathrm{C}=45.9 \%$, $\mathrm{H}=7.5 \%, \mathrm{~N}=12.8 \%$. $\mathrm{C}_{16} \mathrm{H}_{29} \mathrm{~N}_{4} \mathrm{O}_{2} \bullet 3 \mathrm{HCl} \bullet 0.4 \mathrm{H}_{2} \mathrm{O}$ requires $\mathrm{C}=45.4 \%, \mathrm{H}=7.1 \%, \mathrm{~N}=13.2 \%$. 


\section{1-Benzyloxycarbonyl-4,7,10-tris(carbamoylmethyl)-1,4,7,10-tetraazacyclododecane (5)}

The trihydrochloride salt $4(4.1 \mathrm{~g}, 9.8 \mathrm{mmol})$ was dissolved in aqueous sodium hydroxide solution $(20 \mathrm{~mL}, 1 \mathrm{~N})$ and extracted with chloroform $(3 \times 20 \mathrm{~mL})$. The organic extracts were dried $\left(\mathrm{Na}_{2} \mathrm{SO}_{4}\right)$, and the solvents were removed in vacuo. The resultant solid was dissolved in acetonitrile $(60 \mathrm{~mL})$, and anhydrous potassium carbonate $(5.2 \mathrm{~g}, 39.0 \mathrm{mmol})$ was added. The solution was then heated to $60^{\circ} \mathrm{C}$ for $20 \mathrm{~min}$ before bromoacetamide $(5.4 \mathrm{~g}, 39.4 \mathrm{mmol})$ was added, and the reaction mixture stirred at $70{ }^{\circ} \mathrm{C}$ for a further $18 \mathrm{~h}$. The solvents were removed in vacuo, and the residue was dissolved in water $(10 \mathrm{~mL})$ and extracted with dichloromethane $(3 \times 50 \mathrm{~mL})$. The product was purified by flash column chromatography over silica gel eluting with chloroform/methanol (5:2) to yield the title compound as a colorless solid (4.21 g, 90\%). $R_{f}=0.45\left(\mathrm{SiO}_{2}, \mathrm{CHCl}_{3} / \mathrm{MeOH}, 5: 2\right) . \mathrm{Mp}=154-154.5^{\circ} \mathrm{C} .{ }^{1} \mathrm{H} \mathrm{NMR}\left(270 \mathrm{MHz}, \mathrm{CDCl}_{3}\right): \delta=$ $7.30(5 \mathrm{H}, \mathrm{m}, \mathrm{Ph}), 7.01(1 \mathrm{H}, \mathrm{s} \mathrm{br}, \mathrm{NH}), 6.93(2 \mathrm{H}, \mathrm{s} \mathrm{br}, \mathrm{NH}), 6.81(1 \mathrm{H}, \mathrm{s} \mathrm{br}, \mathrm{NH}), 6.70(2 \mathrm{H}, \mathrm{s}$ br, $\mathrm{NH}), 5.06\left(2 \mathrm{H}, \mathrm{s}, \mathrm{OCH}_{2} \mathrm{Ph}\right), 3.44\left(6 \mathrm{H}, \mathrm{s} \mathrm{br}, \mathrm{NCH}_{2} \mathrm{CO}\right), 3.25-2.55(16 \mathrm{H}, \mathrm{m}$, ring $\left.\mathrm{CH}_{2}\right) .{ }^{13} \mathrm{C}$ NMR $\left(67.5 \mathrm{MHz}, \mathrm{CDCl}_{3}\right): \delta=53.3\left(\right.$ ring $\left.\mathrm{CH}_{2}\right), 53.6\left(\right.$ ring $\left.\mathrm{CH}_{2}\right), 54.2\left(\right.$ ring $\mathrm{CH}_{2}$ ), $58.3\left(\mathrm{br}, \mathrm{NCH}_{2} \mathrm{CO}\right), 67.5\left(\mathrm{OCH}_{2} \mathrm{Ph}\right), 128.3$ (3-Ph and 4-Ph), 128.7 (2-Ph), 136.5 (1-Ph), 156.9 $\left(\mathrm{NCO}_{2}\right), 174.6(\mathrm{C}=\mathrm{O}), 174.7(\mathrm{C}=\mathrm{O}) \cdot v_{\max } / \mathrm{cm}^{-1}: 3414(\mathrm{NH}), 2937,2822,1670(\mathrm{C}=\mathrm{O}), 1473$, $1456,1261,1164,1118,995,755,604 . m / z(\mathrm{ESI}+) ; 478\left(100 \%[\mathrm{M}+\mathrm{H}]^{+}\right)$.

\section{1,4,7,10-Tetraazacyclododecane-1,4,7-triacetamide (DO3AM)}

Benzyloxycarbonyl-protected DO3AM $5(2.2 \mathrm{~g}, 4.6 \mathrm{mmol})$ was dissolved in ethanol $(50 \mathrm{~mL})$, and $10 \%$ palladium on carbon $(0.5 \mathrm{~g})$ was added. The reaction mixture was then shaken on a Parr hydrogenator under a hydrogen pressure of $45 \mathrm{psi}$ at room temperature for $12 \mathrm{~h}$. The reaction was filtered, and the solvents were removed in vacuo to afford the title compound as a colorless solid (1.63 g, 99\%). Mp $=232-234{ }^{\circ} \mathrm{C} .{ }^{1} \mathrm{H}$ NMR $\left(270 \mathrm{MHz}, \mathrm{CD}_{3} \mathrm{OD}\right): \delta 3.19(4 \mathrm{H}$, s, $\left.\mathrm{CH}_{2} \mathrm{CO}\right), 3.13\left(2 \mathrm{H}, \mathrm{s}, \mathrm{CH}_{2} \mathrm{CO}\right), 2.73-2.57\left(16 \mathrm{H}, \mathrm{m} \mathrm{br}\right.$, ring $\left.\mathrm{CH}_{2}\right),{ }^{13} \mathrm{C} \mathrm{NMR}(67.5 \mathrm{MHz}$, $\mathrm{CD}_{3}$-OD): $\delta 44.9$ (ring $\mathrm{CH}_{2}$ ), 51.2 (ring $\mathrm{CH}_{2}$ ), 51.4 (ring $\mathrm{CH}_{2}$ ), 52.4 (ring $\mathrm{CH}_{2}$ ), 56.4 $\left(\mathrm{CH}_{2} \mathrm{CO}\right), 57.9\left(\mathrm{CH}_{2} \mathrm{CO}\right), 175.2(\mathrm{C}=\mathrm{O}), 175.4(\mathrm{C}=\mathrm{O}) \cdot v_{\max } / \mathrm{cm}^{-1}: 3390(\mathrm{NH}), 3177(\mathrm{NH})$, 2967, 2832, $1668(\mathrm{C}=\mathrm{O}), 1611,1454,1330,1286,1107,1001,925,776,609 . \mathrm{m} / \mathrm{z}(\mathrm{ESI}+): 344$ $\left(100 \%[\mathrm{M}+\mathrm{H}]^{+}\right), 366\left(63 \%[\mathrm{M}+\mathrm{Na}]^{+}\right)$. Anal. Found $\mathrm{C}=43.4 \%, \mathrm{H}=8.8 \%, \mathrm{~N}=25.0 \%$ $\mathrm{C}_{14} \mathrm{H}_{29} \mathrm{~N}_{7} \mathrm{O}_{3} \cdot 2.5 \mathrm{H}_{2} \mathrm{O}$ requires $\mathrm{C}=43.3 \%, \mathrm{H}=8.8 \%, \mathrm{~N}=25.2 \%$.

\section{1-Methlyene-( $p$-nitrophenol)-1,4,7,10-tetraazacyclododecane-4,7,10-triacetamide (NP- D03AM)}

To a solution of DO3AM ( $0.13 \mathrm{~g}, 0.38 \mathrm{mmol})$ in ethanol $(100 \mathrm{~mL})$ was added 2-hydroxy-5nitrobenzyl bromide $(0.09 \mathrm{~g}, 0.38 \mathrm{mmol})$ and the mixture heated to $60^{\circ} \mathrm{C}$. After $1 \mathrm{~h}$ potassium carbonate $(0.05 \mathrm{~g}, 0.38 \mathrm{mmol})$ was added and the reaction stirred at $60{ }^{\circ} \mathrm{C}$ for a further $12 \mathrm{~h}$. After cooling to room temperature the reaction mixture was filtered, and the solvents were removed in vacuo. The residue was then crystallized for a mixture of methanol and acetonitrile to afford the ligand as a pale-yellow solid $(1.2 \mathrm{~g}, 65 \%)$. $\mathrm{Mp}=103-105{ }^{\circ} \mathrm{C} .{ }^{1} \mathrm{H} \mathrm{NMR}(270 \mathrm{MHz}$, $\left.\mathrm{D}_{2} \mathrm{O}\right): \delta=8.09(1 \mathrm{H}, \mathrm{s}, 3-\mathrm{Ph}), 7.99\left(1 \mathrm{H}, \mathrm{d},{ }^{3} J_{\mathrm{H}-\mathrm{H}}=9 \mathrm{~Hz}, 5-\mathrm{Ph}\right), 6.47\left(1 \mathrm{H}, \mathrm{d},{ }^{3} J_{\mathrm{H}-\mathrm{H}}=9 \mathrm{~Hz}, 6-\right.$ $\mathrm{Ph}), 4.43\left(2 \mathrm{H}, \mathrm{s}, \mathrm{CH}_{2} \mathrm{Ar}\right), 3.20\left(4 \mathrm{H}, \mathrm{s}, \mathrm{CH}_{2} \mathrm{CO}\right), 3.12\left(2 \mathrm{H}, \mathrm{s}, \mathrm{CH}_{2}-\mathrm{CO}\right), 2.52-2.82(16 \mathrm{H}, \mathrm{m} \mathrm{br}$, ring $\left.\mathrm{CH}_{2} \mathrm{~N}\right) .{ }^{13} \mathrm{C}$ NMR $\left(67.5 \mathrm{MHz}, \mathrm{CDCl}_{3}\right): \delta=44.7\left(\operatorname{ring} \mathrm{CH}_{2} \mathrm{~N}\right), 49.5\left(\operatorname{ring} \mathrm{CH}_{2} \mathrm{~N}\right), 51.2$ (ring $\left.\mathrm{CH}_{2} \mathrm{~N}\right)$, $53.4\left(\right.$ ring $\left.\mathrm{CH}_{2} \mathrm{~N}\right), 56.1\left(\mathrm{CH}_{2} \mathrm{CO}\right), 66.4\left(\mathrm{CH}_{2} \mathrm{CO}\right), 67.7\left(\mathrm{CH}_{2} \mathrm{Ar}\right), 118.7(2-\mathrm{Ph})$, 126.6 (5-Ph), 127.0 (3-Ph), $127.3(6-\mathrm{Ph}), 134.7$ (4-Ph), $173.2(1-\mathrm{Ph}), 176.3(\mathrm{C}=\mathrm{O}), 176.6$ $(\mathrm{C}=\mathrm{O}) . \mathrm{m} / z(\mathrm{ESI}+): 495\left(100 \%[\mathrm{M}+\mathrm{H}]^{+}\right)$. Anal. Found $\mathrm{C}=46.0 \%, \mathrm{H}=7.4 \%, \mathrm{~N}=20.8 \%$ $\mathrm{C}_{21} \mathrm{H}_{34} \mathrm{~N}_{8} \mathrm{O}_{6} \cdot 3 \mathrm{H}_{2} \mathrm{O}$ requires $\mathrm{C}=46.0 \%, \mathrm{H}=7.4 \%, \mathrm{~N}=20.4 \%$.

\section{Preparation of the Lanthanide(III) Complexes of NP-DO3A}

An aqueous lanthanide chloride solution $(0.4 \mathrm{mmol}$ in $1.5 \mathrm{~mL})$ was added in $200-\mu \mathrm{L}$ aliquots to a solution of NP-DO3A $(0.2 \mathrm{~g}, 0.4 \mathrm{mmol})$ in water $(5 \mathrm{~mL}, \mathrm{pH} 2)$. The $\mathrm{pH}$ of the solution was maintained between 4 and 5 throughout the addition process via the addition of $1 \mathrm{~N} \mathrm{KOH}$. 
Complexation progress was monitored by reverse phase HPLC (PRP-1 $10 \mu \mathrm{m} / 250 \mathrm{~mm} \times 4.1$ $\mathrm{mm}, 30 \% \mathrm{MeOH}, \lambda_{\max }=254 \mathrm{~nm}$, flow rate of $1 \mathrm{~mL} / \mathrm{min}$; ligand $t_{\mathrm{R}}=2.6$ min, chelate $t_{\mathrm{R}}=10.9$ min). HRMS (MALDI): $\mathrm{C}_{21} \mathrm{H}_{29} \mathrm{~N}_{5} \mathrm{O}_{9} \mathrm{Eu}\left([\mathrm{EuLH}]^{+}\right)$requires 648.1278, found 648.1288; $\mathrm{C}_{21} \mathrm{H}_{29} \mathrm{~N}_{5} \mathrm{O}_{9} \mathrm{Gd}\left([\mathrm{GdLH}]^{+}\right)$requires 653.1260 , found $653.1227 ; \mathrm{C}_{21} \mathrm{H}_{29} \mathrm{~N}_{5} \mathrm{O}_{9} \mathrm{~Tb}\left([\mathrm{TbLH}]^{+}\right)$ requires 654.1221, found 654.1212; $\mathrm{C}_{21} \mathrm{H}_{29} \mathrm{~N}_{5} \mathrm{O}_{9} \mathrm{Dy}\left([\mathrm{DyLH}]^{+}\right.$) requires 659.1257, found 659.1234 .

\section{Preparation of the Lanthanide(III) Complexes of NP-DO3AM}

To a solution of NP-DO3AM $(50 \mathrm{mg}, 0.1 \mathrm{mmol})$ in water $(4 \mathrm{~mL})$ was added a solution of the appropriate lanthanide chloride or triflate $(0.1 \mathrm{mmol})$ in aqueous solution $(4 \mathrm{~mL})$. The reaction was heated at $60 \mathrm{C}$ for $18 \mathrm{~h}$. After cooling to room temperature the complex was dried by lyophilization. The complexes were employed without further purification. $m / z(\mathrm{ESI}+)$; $\mathrm{Eu}(\mathrm{NP}-$ DO3AM), $643\left(100 \%\left[{ }^{151} \mathrm{EuL}\right]^{+}\right), 645\left(100 \%\left[{ }^{153} \mathrm{EuL}\right]^{+}\right)$; Gd(NP-DO3AM), $650(100 \%$ $\left.[\mathrm{GdL}]^{+}\right)$; an appropriate isotope pattern was observed; Tb(NP-DO3AM), $651\left(100 \%[\mathrm{TbL}]^{+}\right)$; Dy(NP-DO3AM), $654\left(100 \%\left[\mathrm{DyL}^{+}\right)\right.$; an appropriate isotope pattern was observed.

\section{Crystal Structure Determination of Eu(NP-DO3AM) $\left(\mathrm{H}_{2} \mathrm{O}\right)-\left(\mathrm{CF}_{3} \mathrm{SO}_{3}\right)_{2}$}

The structure is presented in Figure 1. Crystals were grown from aqueous solution at $\mathrm{pH} 5$ by slow evaporation at room temperature: $\mathrm{C}_{23} \mathrm{H}_{35} \mathrm{EuF}_{6} \mathrm{~N}_{8} \mathrm{O}_{13} \mathrm{~S}_{2}$, mass $=961.67$, triclinic, $P \overline{\mathrm{I}}, a$ $=11.042(2) \AA, b=11.956$ (2) $\AA, c=13.723$ (3) $\AA, \alpha=92.36(3)^{\circ}, \beta=105.63(3)^{\circ}, \gamma=101.76$ (3) ${ }^{\circ}, U=1699.2(6) \AA^{3}, Z=2, D_{\chi}=1.880 \mathrm{gcm}^{-3}, \lambda(\mathrm{Mo} \mathrm{K} \alpha)=0.71073 \AA, \mu=2.076 \mathrm{~mm}^{-1}$, $F(000)=964, T=293 \mathrm{~K}$. The sample was studied on a Bruker CCD 1000. The data collection gave 4844 unique reflections. Refinement was performed using a full-matrix least-squares method on $F^{2}$ using SHELXTL, version 5. This procedure afforded a final $R(I>2 \sigma(I))$ of R1 $=0.0422 ; \mathrm{wR} 2=0.1741$. For all data $\mathrm{R} 1=0.0828 ; \mathrm{wR} 2=0.2168$.

\section{Kinetic Stability Profiles of ${ }^{177} \mathrm{Lu}(\mathrm{NP}-\mathrm{DO} 3 \mathrm{~A})$}

A stock ${ }^{177} \mathrm{Lu}$ solution was prepared by adding $2 \mu \mathrm{L}$ of a $0.3 \mathrm{mM}$ solution of ${ }^{177} \mathrm{LuCl}_{3}$ in 0.1 $\mathrm{N} \mathrm{HCl}$ to $2 \mathrm{~mL}$ of a $0.3 \mathrm{mM}$ solution of $\mathrm{LuCl} 3$ also in $0.1 \mathrm{~N} \mathrm{HCl}$. A similar stock solution of the ligand was prepared in deionized water. The complex was prepared at a 5:1 ligand/metal ratio by combining appropriate aliquots of each standard solution at $\mathrm{pH} 2$. The $\mathrm{pH}$ was then adjusted to $\mathrm{pH} 7$ using $0.1 \mathrm{~N} \mathrm{NaOH}$. The extent of complex formation was determined by passing a sample of the complex solution through a Sephadex G-50 column eluting with 4:1 saline $\left(0.85 \% \mathrm{NaCl} / \mathrm{NH}_{4} \mathrm{OH}\right)$. Two $3-\mathrm{mL}$ fractions were collected, and the amount of radioactivity in the combined elutions was compared to that remaining on the resin. Only free metal was retained on the resin. Once the complexation reaction had reached $>98 \%$ completion, a $\mathrm{pH}$ stability profile was then generated. Aliquots were taken from the complexation reaction at $\mathrm{pH} 7$, and the $\mathrm{pH}$ adjusted to high and low $\mathrm{pH}$ points. The solutions were then allowed to equilibrate, and aliquots were removed at intervals ( $5 \mathrm{~min}, 2 \mathrm{~h}, 6 \mathrm{~h}$, and $24 \mathrm{~h}$ ). The amount of free lutetium versus the amount of complex present in each individual sample $\mathrm{pH}$ point was then measured by using the radioactivity counting method described above. To assess the effect of $\mathrm{Zn}^{2+}$ the ${ }^{177} \mathrm{Lu}$ complex was prepared with a 3:1 ligand/metal ratio, the $\mathrm{pH}$ was adjusted to 7.4 , and 3 equiv of $\mathrm{ZnCl}_{2}$ were added. Aliquots were removed from the reaction at (5 min, 2 $\mathrm{h}, 16 \mathrm{~h}$, and $24 \mathrm{~h}$ ), and the extent of transmetalation was measured using the same radioactivity counting method.

\section{Supplementary Material}

Refer to Web version on PubMed Central for supplementary material. 


\section{Acknowledgment}

We thank the National Institutes of Health (RR-02584, CA-84697, CA96019, and EB-04285), the Robert A Welch Foundation (AT-584), and the Texas Advanced Technology Program for financial assistance.

\section{References}

1. Caravan P, Ellison JJ, McMurry TJ, Lauffer RB. Chem. Rev 1999;99:2293-2352. [PubMed: 11749483]

2. Merbach, AE.; Toth, E. The Chemistry of Contrast Agents in Medical Magnetic Resonance Imaging. New York: Wiley; 2001.

3. Sigel, A.; Sigel, H. The Lanthanides and Their Interrelations with Biosystems. Vol. Vol. 40. New York: Dekker; 2003.

4. Moats RA, Fraser SE, Meade TJ. Angew. Chem., Int. Ed 1997;36:726-728.

5. Lowe MP, Parker D, Reany O, Aime S, Botta M, Castellano G, Gianolio E, Pagliarin R. J. Am. Chem. Soc 2001;123:7601-7609. [PubMed: 11480981]

6. Li, W-h; Fraser, SE.; Meade, TJ. J. Am. Chem. Soc 1999;121:1413-1414.

7. Li, W-h; Parigi, G.; Fragai, M.; Luchinat, C.; Meade, TJ. Inorg. Chem 2002;41:4018-4024. [PubMed: 12132928]

8. Hanaoka K, Kikuchi K, Urano Y, Nagano T. J. Chem. Soc., Perkin Trans. 2 2001:1840-1843.

9. Aime S, Batsanov AS, Botta M, Howard JAK, Lowe MP, Parker D. New J. Chem 1999;23:669-670.

10. Brandes S, Gros C, Denat F, Pullumbi P, Guilard R. Bull. Soc. Chim. Fr 1996;133:65-73.

11. Aime S, Barge A, Bruce JI, Botta M, Howard JAK, Moloney JM, Parker D, de Sousa AS, Woods M. J. Am. Chem. Soc 1999;121:5762-5771.

12. Dickins RS, Howard JAK, Maupin CL, Moloney JM, Parker D, Riehl JP, Siligardi G, Williams JAG. Chem. Eur. J 1999;5:1095-1105.

13. Zhang X, Chang CA, Brittain HG, Garrison JM, Telser J, Tweedle MF. Inorg. Chem 1992;31:55975600.

14. Toth E, Pubanz D, Vauthey S, Helm L, Merbach AE. Chem. Eur. J 1996;2:1607-1615.

15. Horrocks WD Jr, Sudnick DR. J. Am. Chem. Soc 1979;101:334-340.

16. Horrocks WD Jr, Sudnick DR. Acc. Chem. Res 1981;14:384-392.

17. Beeby A, Clarkson IM, Dickins RS, Faulkner S, Parker D, Royle L, de Sousa AS, Williams JAG, Woods M. J. Chem. Soc., Perkin Trans. 2 1999:493-504.

18. Parker D. Coord. Chem. Rev 2000;205:109-130.

19. Alpoim MC, Urbano AM, Geraldes CFGC, Peters JA. J. Chem. Soc., Dalton Trans 1992:463-467.

20. Botta M, Aime S, Barge A, Bobba G, Dickins RS, Parker D, Terreno E. Chem. Eur. J 2003;9:21022109.

21. Bruce JI, Dickins RS, Govenlock LJ, Gunnlaugsson T, Lopinski S, Lowe MP, Parker D, Peacock RD, Perry JJB, Aime S, Botta M. J. Am. Chem. Soc 2000;122:9674-9684.

22. Dickins RS, Aime S, Batsanov AS, Beeby A, Botta M, Bruce JI, Howard JAK, Love CS, Parker D, Peacock RD, Puschmann H. J. Am. Chem. Soc 2002;124:12697-12705. [PubMed: 12392417]

23. Lowe MP, Parker D. Chem. Commun 2000:707-708.

24. Messeri D, Lowe MP, Parker D, Botta M. Chem. Commun 2001:2742-2743. 

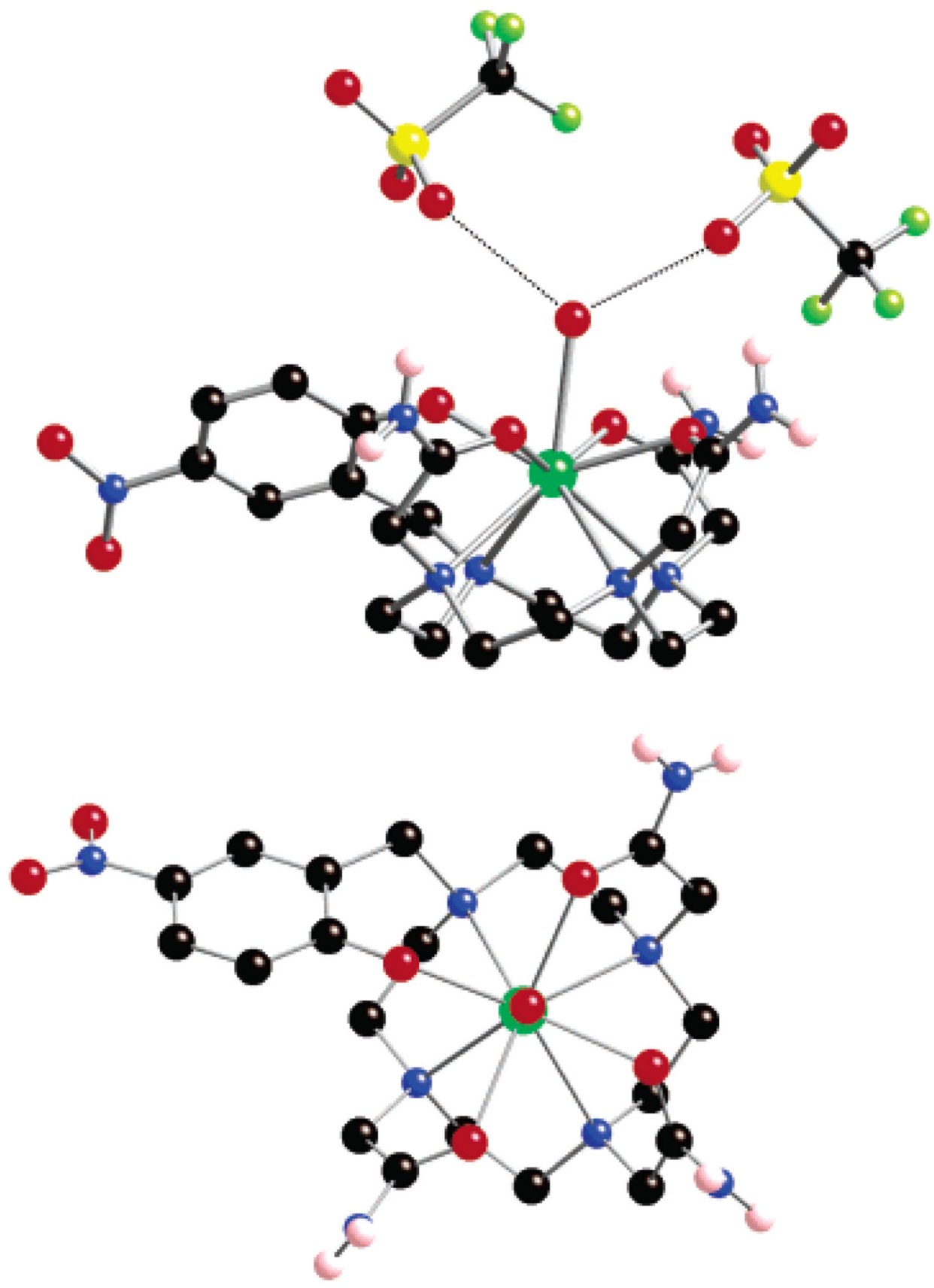

Figure 1.

Crystal structure of $\mathrm{Eu}(\mathrm{NP}-\mathrm{DO} 3 \mathrm{AM})\left(\mathrm{H}_{2} \mathrm{O}\right)\left(\mathrm{CF}_{3} \mathrm{SO}_{2}{ }^{-}\right)_{2}$ showing a side view (upper) and top view (lower). Hydrogen atoms bonded to carbon have been omitted for clarity. The structure shown is the $\Delta(\lambda \lambda \lambda \lambda)$ conformer, the $\Lambda(\delta \delta \delta \delta)$ conformer, cocrystallized in the $P \overline{1}$ unit cell, is not shown. The dotted lines indicate the hydrogen-bonding interactions of the coordinated water molecule and the triflate anions. An ORTEP rendering of the structure is included in the ESI. 


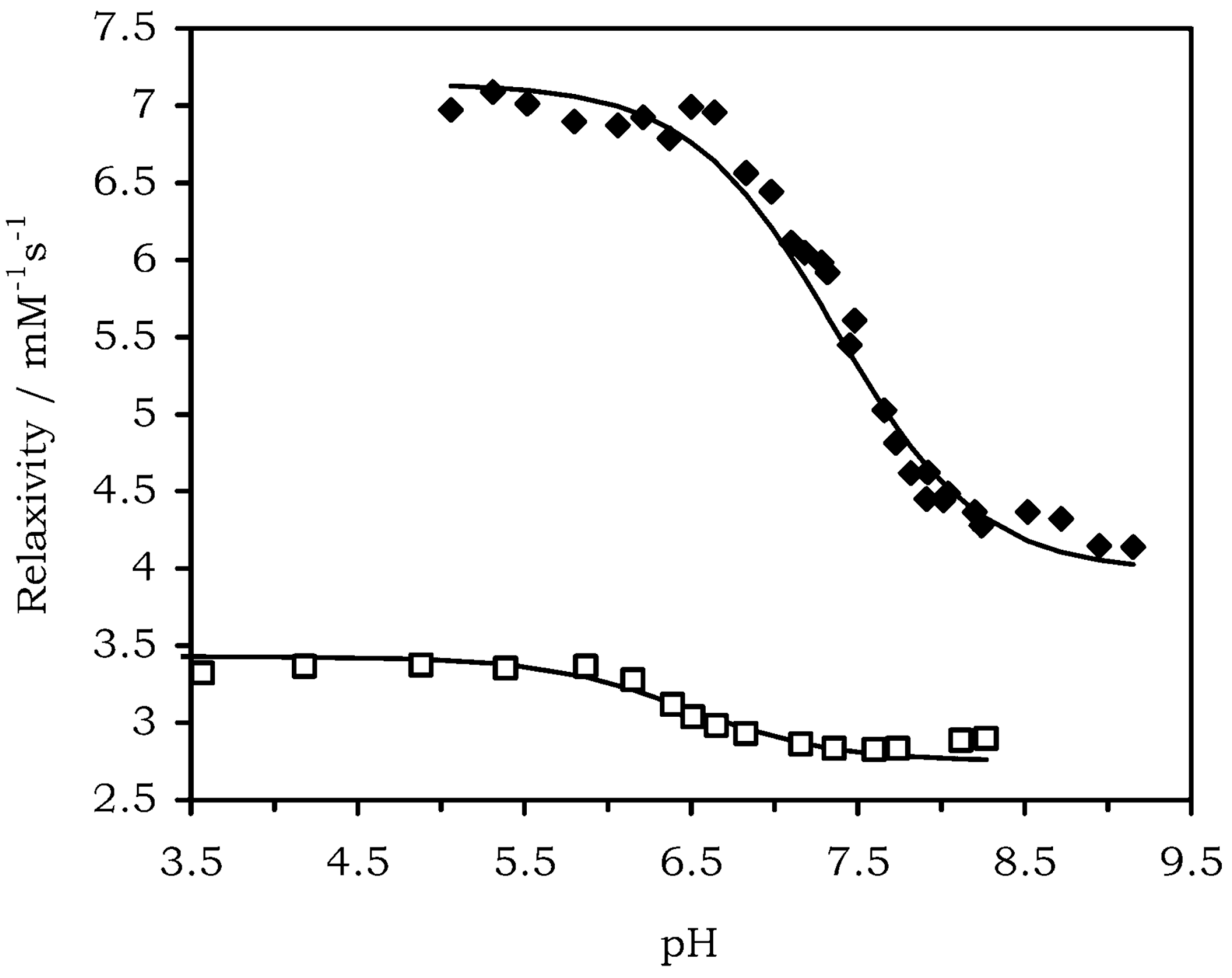

Figure 2.

Relaxivity $\mathrm{pH}$ profiles of Gd(NP-DO3A) (filled diamonds) and Gd(NP-DO3AM) (open squares) recorded at $25^{\circ} \mathrm{C}$ and $20 \mathrm{MHz}$. 


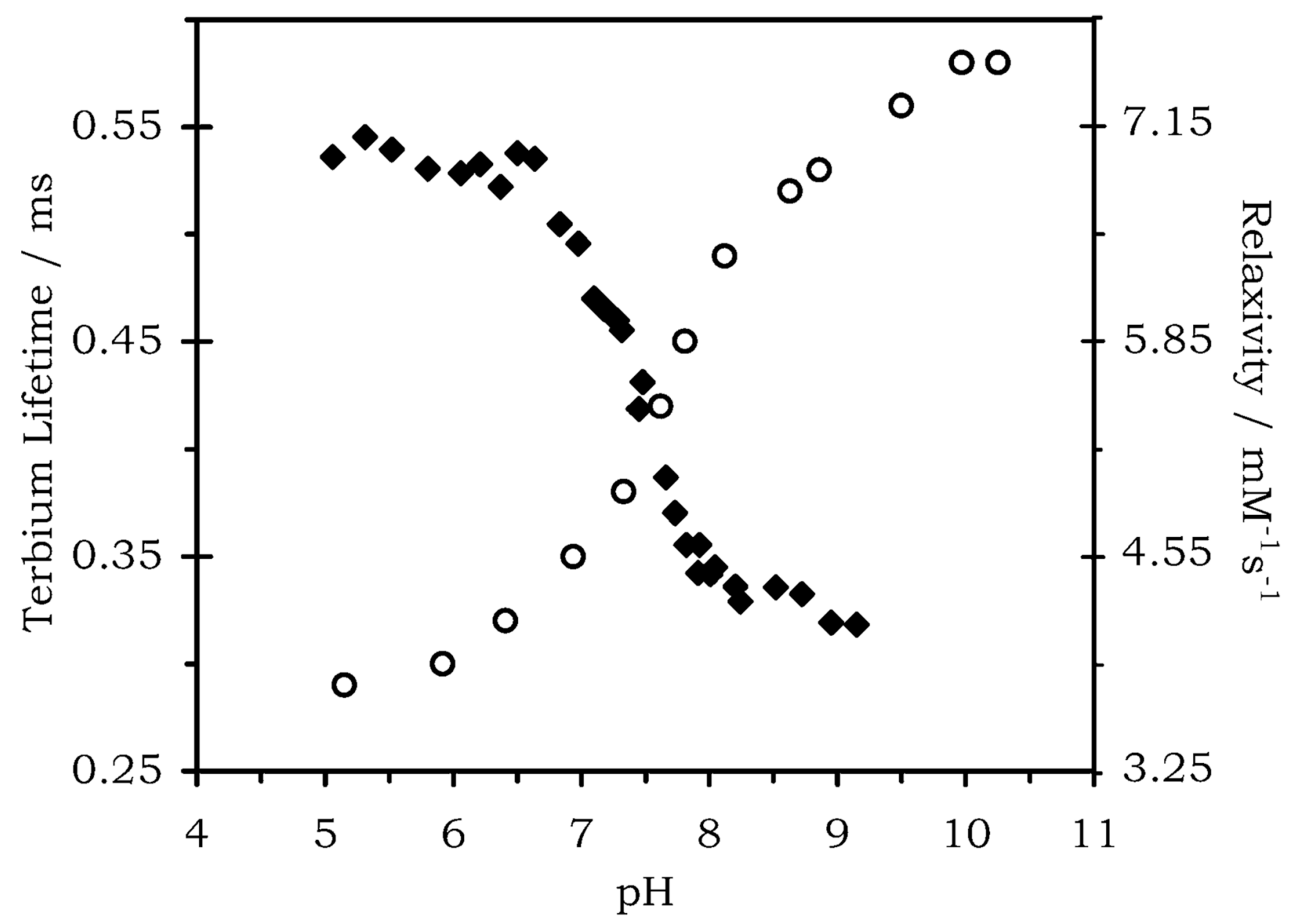

Figure 3.

Effect of $\mathrm{pH}$ on the terbium emission lifetime of Tb(NP-DO3A) at $\left(\lambda_{\mathrm{ex}}=270 \mathrm{~nm}, \lambda_{\mathrm{em}}=545\right.$ $\mathrm{nm})$ (open circles), shown with the relaxivity profile of Gd(NP-DO3A) (filled diamonds). 

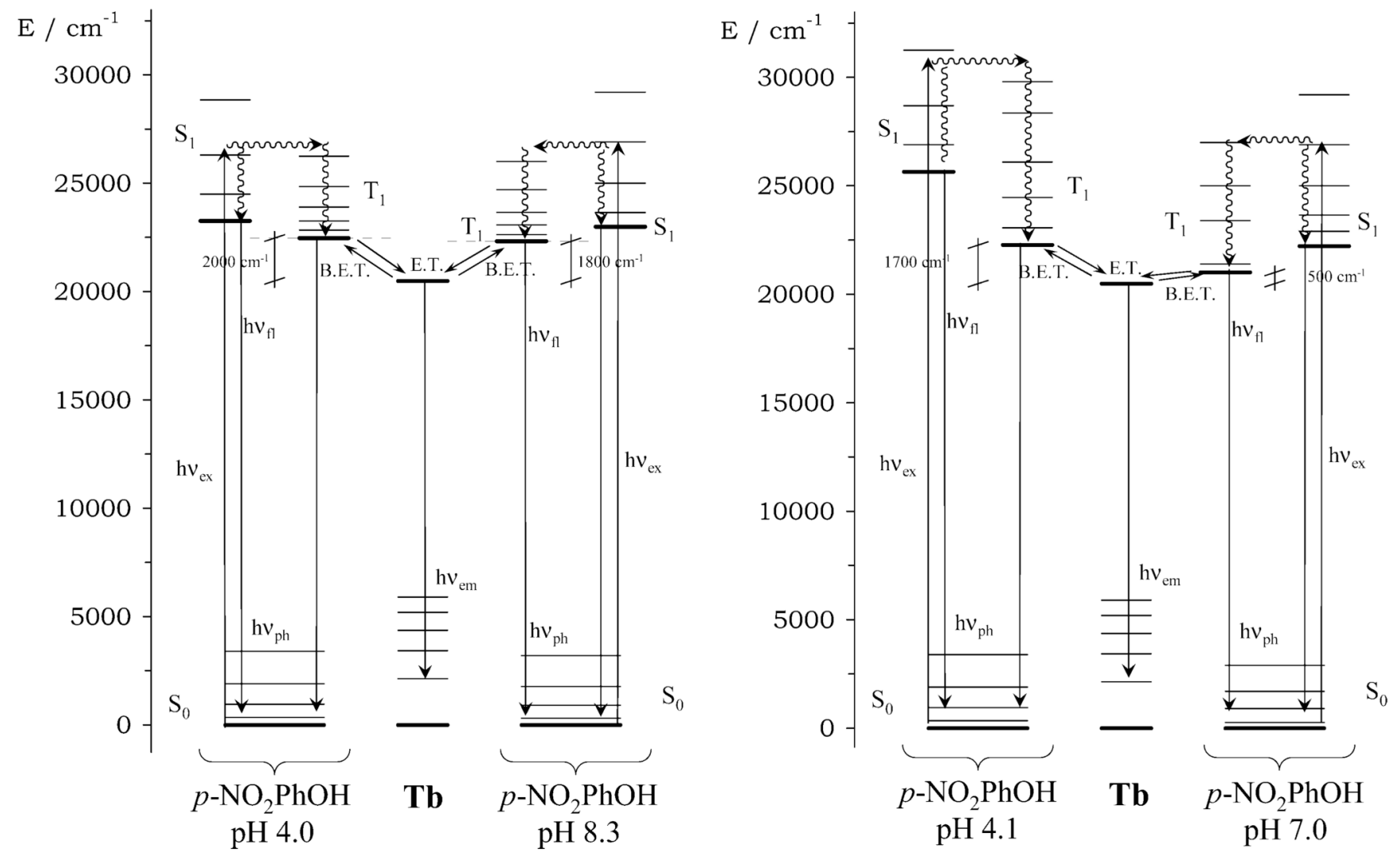

Figure 4.

Jablonski diagrams of the terbium complexes of NP-DO3A (left) and NP-DO3AM (right) showing that the proximity of the triplet energy level of the nitrophenol group causes substantial back energy transfer in these complexes. 


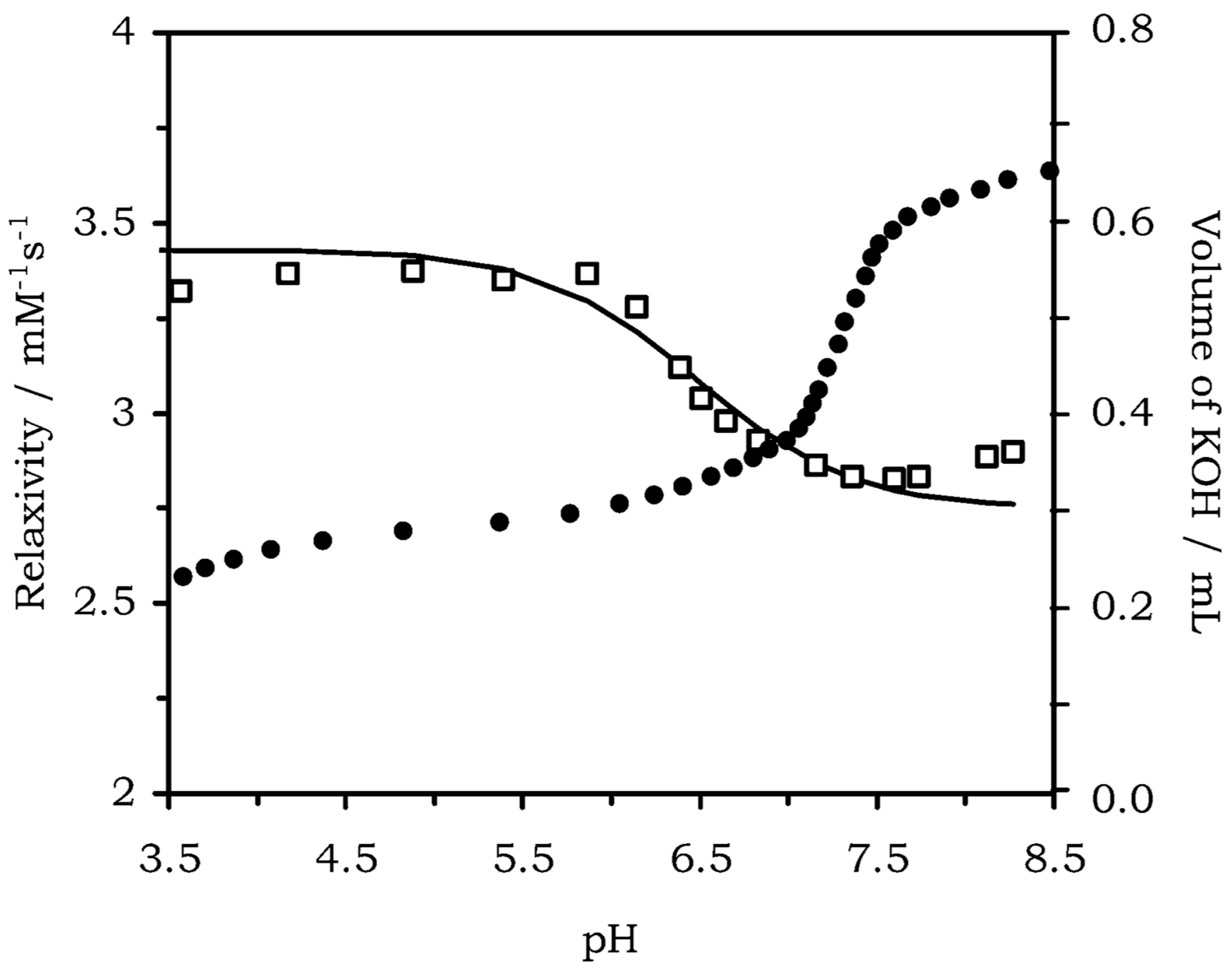

Figure 5.

Relaxivity $\mathrm{pH}$ profile of Gd(NP-DO3AM) plotted alongside the data from the potentiometric titration of $\mathrm{Yb}(\mathrm{NP}-\mathrm{DO} 3 \mathrm{AM})$. The $\mathrm{p} K_{\mathrm{a}}$ of the complex at 7.22 corresponds to the onset of the relaxivity enhancement as the $\mathrm{pH}$ is lowered. 


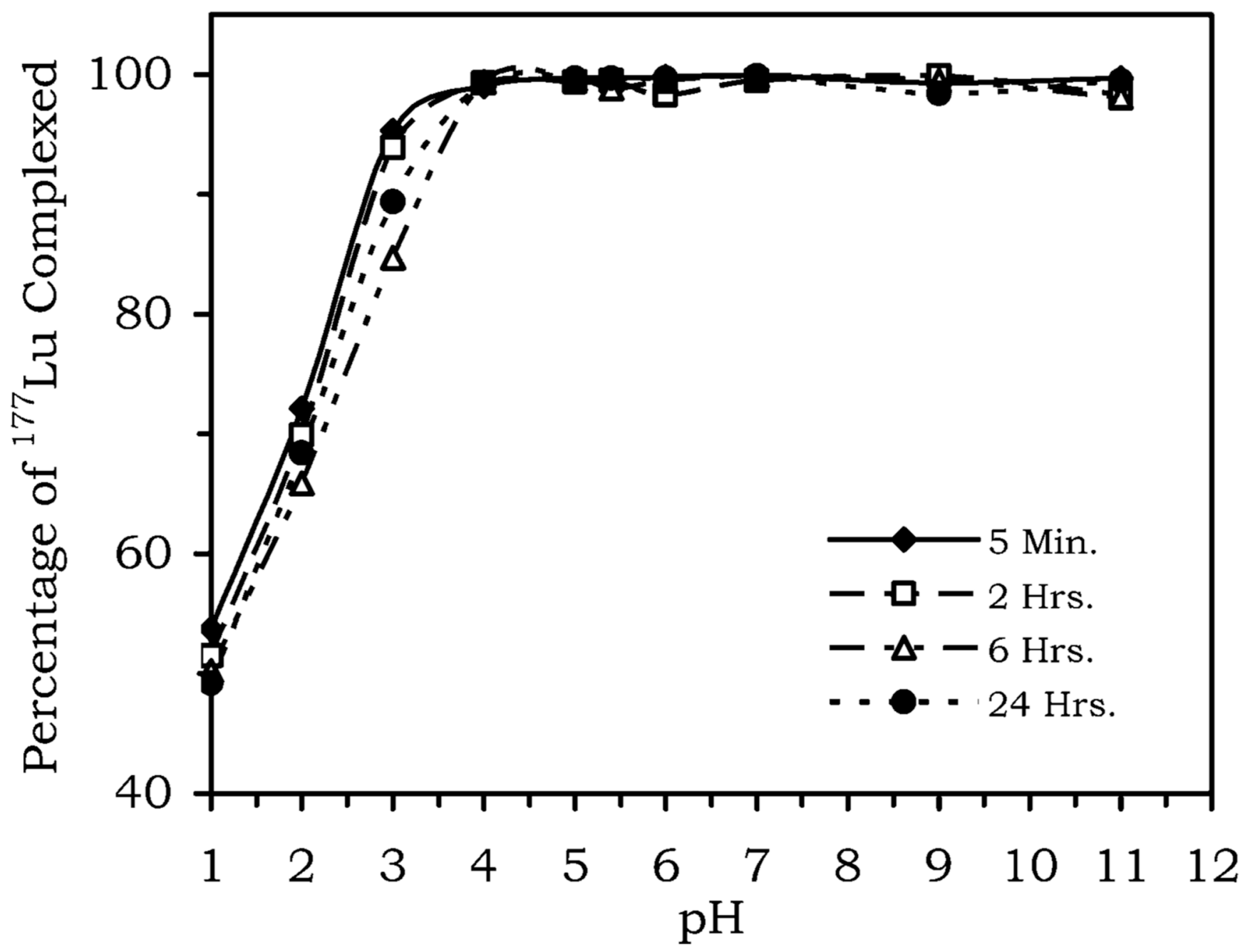

Figure 6.

Complex Lu(NP-DO3A) is stable over the $\mathrm{pH}$ range $4-11$ for up to $24 \mathrm{~h}$, with greater than $98 \%$ of the complex remaining intact in this $\mathrm{pH}$ range. Dissociation of the complex is only observed at $\mathrm{pH} 3$ or below. 


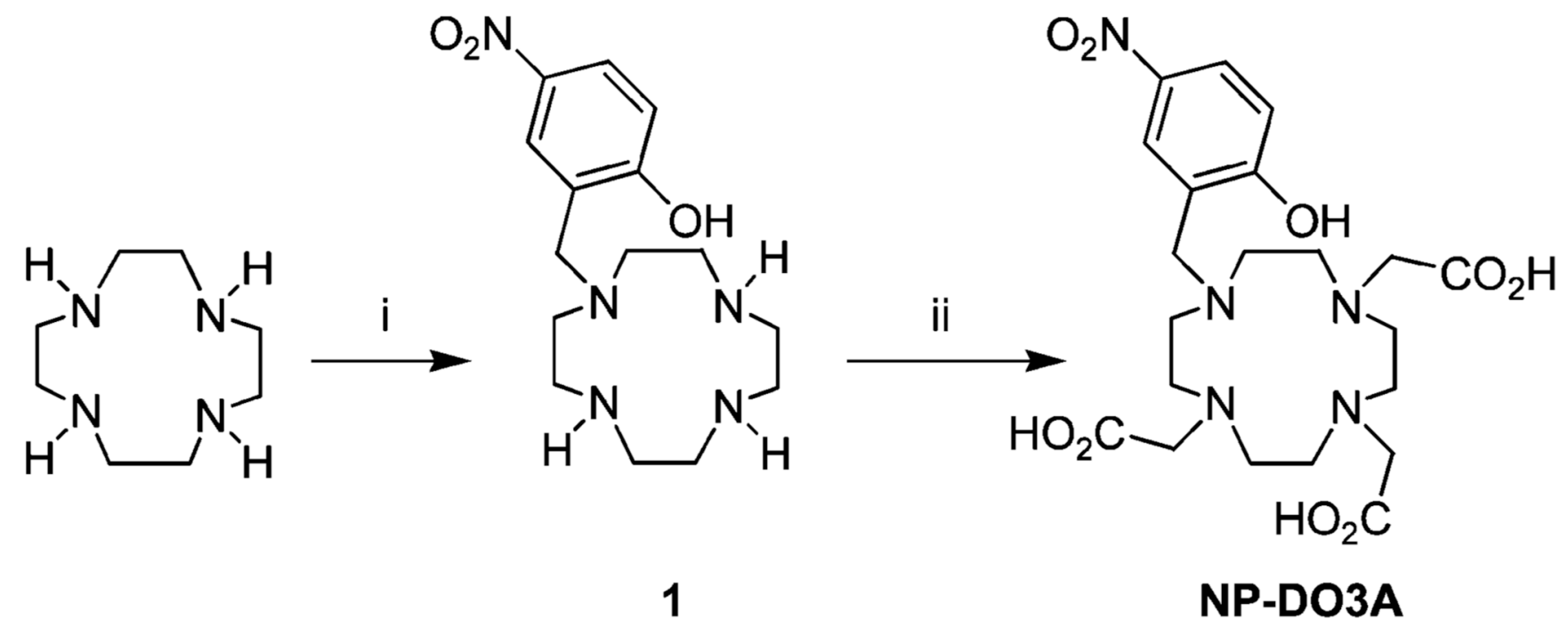

Scheme 1.

Synthesis of NP-DO3Aa

${ }^{a}$ Reagents and conditions: i. 2-hydroxyl-5-nitrobenzyl bromide/dioxane (55\%) ii.

$\mathrm{BrCH}_{2} \mathrm{CO}_{2} \mathrm{H} / \mathrm{H}_{2} \mathrm{O} / \mathrm{pH} 8.5$ (49\%). 

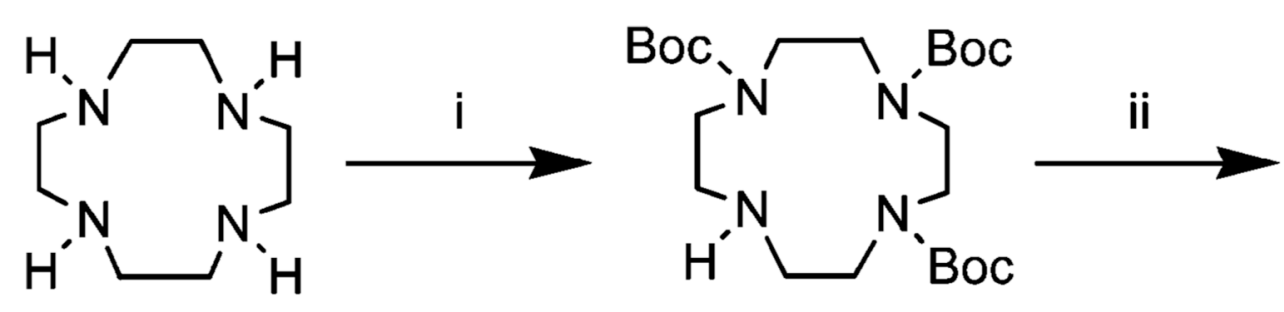

2

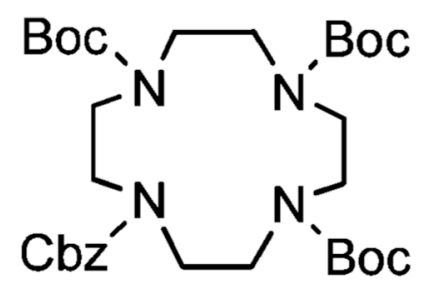

3

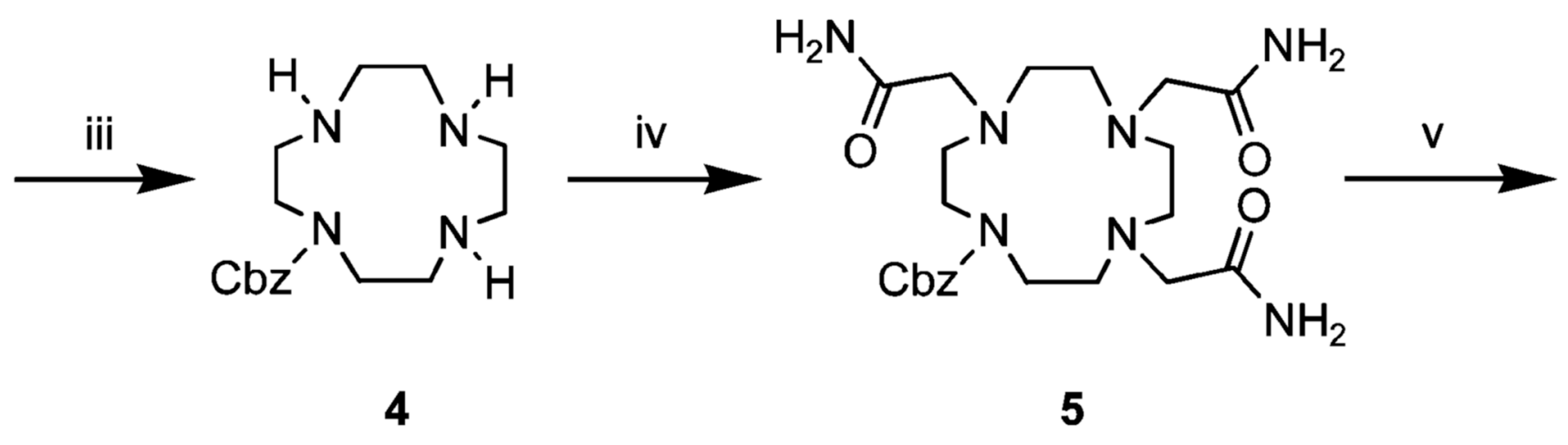

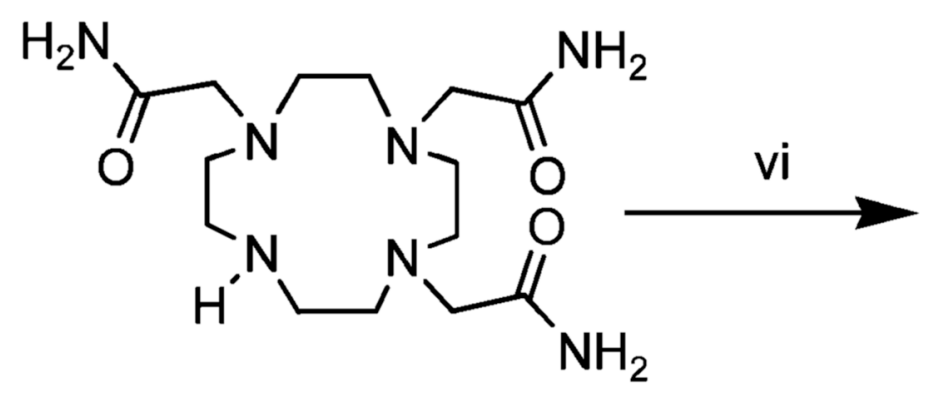

DO3AM

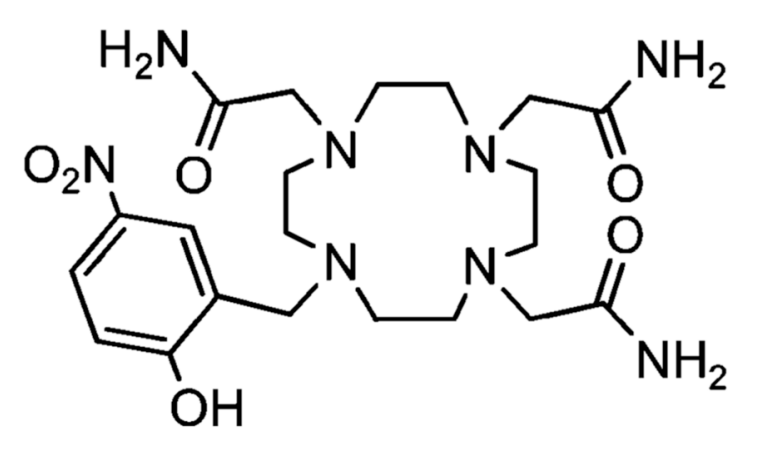

NP-D03AM

Scheme 2.

Synthesis of NP-DO3AMa

a Reagents and conditions: i. (Boc) $)_{2} \mathrm{O} / \mathrm{CHCl}_{3}(90 \%)$, ii. $\mathrm{BnOCOCl} / \mathrm{Et}_{3} \mathrm{~N} / \mathrm{CHCl}_{3}(98 \%)$, iii. $\mathrm{HCl} / \mathrm{MeOH}\left(94 \%\right.$ ), iv. $\mathrm{BrCH}_{2} \mathrm{CONH}_{2} / \mathrm{MeCN}_{2} \mathrm{~K}_{2} \mathrm{CO}_{3}(90 \%)$, v. $\mathrm{H}_{2} / 10 \%$ Pd on C/EtOH (99\%), vi. 2-hydroxyl-5-nitrobenzyl bromide/ $\mathrm{K}_{2} \mathrm{CO}_{3} / \mathrm{EtOH}(65 \%)$. 
<smiles>O=C(O)CN1CCN(CC(=O)O)CCN(CC(=O)O)CCN(CC(=O)O)CC1</smiles>

\section{DOTA}<smiles>O=C(O)CN1CCNCCN(CC(=O)O)CCN(CC(=O)O)CC1</smiles>

DO3A<smiles>O=C(O)CN1CCN(CC(=O)O)Cc2cc([N+](=O)[O-])ccc2OCN(CC(=O)O)N(CC(=O)O)CC1</smiles>

NP-DO3A<smiles>NC(=O)CN1CCNCCN(CC(N)=O)CN(CC(N)=O)CC1</smiles>

DO3AM<smiles>NC(=O)CN1CCN(CC(N)=O)COc2ccc([N+](=O)[O-])cc2CN(CC(N)=O)CC1</smiles>

NP-DO3AM

Chart 1.

Structures of 1-Methlyene-( $p$-NitroPhenol)-1,4,7,10-tetraazacycloDOdecane-4,7,10triAcetate (NP-DO3A) and 1-Methlyene- ( $p$-NitroPhenol)-1,4,7,10tetraazacycloDOdecane-4,7,10-triacetAMide (NP-DO3AM) 
Table 1

Crystal Structure Determination of Eu(NP-DO3AM) $\left(\mathrm{H}_{2} \mathrm{O}\right)\left(\mathrm{CF}_{3} \mathrm{SO}_{2}{ }^{-}\right)_{2}$

\begin{tabular}{ll}
\hline formula & $\mathrm{C}_{23} \mathrm{H}_{35} \mathrm{EuF}_{6} \mathrm{~N}_{8} \mathrm{O}_{13} \mathrm{~S}_{2}$ \\
formula mass & 961.67 \\
temperature & $293 \mathrm{~K}$ \\
crystal system & triclcinic \\
space group & $P \mathrm{I}$ \\
unit cell & \\
$a(\AA)$ & $11.042(2)$ \\
$b(\AA)$ & $11.956(2)$ \\
$c(\AA)$ & $13.723(3)$ \\
$\alpha($ deg $)$ & 92.36 \\
$\beta($ deg $)$ & 105.63 \\
$\gamma($ deg $)$ & $101.76(3)$ \\
volume $\left(\AA^{3}\right)$ & $1699.2(6)$ \\
$Z$ & 2 \\
final $R(\mathrm{I}>2 \sigma(\mathrm{I}))$ & $\mathrm{R} 1=0.0422 ; \mathrm{wR} 2=0.1741$ \\
$R$ (all data) & $\mathrm{R} 1=0.0828 ; \mathrm{wR} 2=0.2168$ \\
$\mathrm{GOF}$ & 1.01 \\
\hline
\end{tabular}


Table 2

Selected Angles (deg) and Bond Distances $(\AA)$ from the Crystal Structure of Eu $(\mathrm{NP}-\mathrm{DO} 3 \mathrm{AM})\left(\mathrm{H}_{2} \mathrm{O}\right)\left(\mathrm{CF}_{3} \mathrm{SO}_{2}{ }^{-}\right)^{2}$

\begin{tabular}{|c|c|}
\hline \multicolumn{2}{|c|}{ Angles } \\
\hline $\mathrm{N} 1-\mathrm{C} 2-\mathrm{C} 3-\mathrm{N} 4$ & 56.7 \\
\hline N4-C5-C6-N7 & 60.4 \\
\hline N7-C8-C9-N10 & 61.0 \\
\hline N10-C11-C12-N1 & 64.4 \\
\hline $\mathrm{N} 4-\mathrm{C} 41-\mathrm{C} 42-\mathrm{O} 41$ & 13.7 \\
\hline N7-C71-C72-O71 & 3.3 \\
\hline N10-C101-C102-O101 & 26.7 \\
\hline $\mathrm{N}(1)-\mathrm{Eu}(1)-\mathrm{O}(15)$ & $74.4(2)$ \\
\hline $\mathrm{N}(4)-\mathrm{Eu}(1)-\mathrm{O}(41)$ & $65.4(2)$ \\
\hline $\mathrm{N}(7)-\mathrm{Eu}(1)-\mathrm{O}(71)$ & $63.9(2)$ \\
\hline $\mathrm{N}(10)-\mathrm{Eu}(1)-\mathrm{O}(101)$ & $64.8(2)$ \\
\hline $\mathrm{O}(15)-\mathrm{Eu}(1)-\mathrm{O}(1 \mathrm{~W})$ & $68.2(2)$ \\
\hline $\mathrm{O}(41)-\mathrm{Eu}(1)-\mathrm{O}(1 \mathrm{~W})$ & $75.0(2)$ \\
\hline $\mathrm{O}(71)-\mathrm{Eu}(1)-\mathrm{O}(1 \mathrm{~W})$ & $68.0(2)$ \\
\hline $\mathrm{O}(101)-\mathrm{Eu}(1)-\mathrm{O}(1 \mathrm{~W})$ & $70.9(2)$ \\
\hline \multicolumn{2}{|c|}{ Bond Lengths } \\
\hline $\mathrm{Eu}(1)-\mathrm{O}(1 \mathrm{~W})$ & $2.486(5)$ \\
\hline $\mathrm{Eu}(1)-\mathrm{O}(15)$ & $2.242(5)$ \\
\hline $\mathrm{Eu}(1)-\mathrm{O}(41)$ & $2.382(5)$ \\
\hline $\mathrm{Eu}(1)-\mathrm{O}(71)$ & $2.403(5)$ \\
\hline $\mathrm{Eu}(1)-\mathrm{O}(101)$ & $2.387(5)$ \\
\hline $\mathrm{Eu}(1)-\mathrm{N}(1)$ & $2.643(6)$ \\
\hline $\mathrm{Eu}(1)-\mathrm{N}(4)$ & $2.685(6)$ \\
\hline $\mathrm{Eu}(1)-\mathrm{N}(7)$ & $2.745(6)$ \\
\hline $\mathrm{Eu}(1)-\mathrm{N}(10)$ & $2.676(6)$ \\
\hline
\end{tabular}

$a_{\text {The full data set has been deposited with the Cambridge Crystallographic Database. }}$ 